\title{
A implementação da Procuradoria Europeia - a emergência de um modelo de intervenção penal entre a cooperação e a integração penal?
}

\author{
The implementation of the European Public Prosecutor's Office - \\ the emergence of a model of criminal intervention between \\ cooperation and criminal integration?
}

\author{
Margarida Santos ${ }^{1}$ \\ Universidade do Minho - Braga/Portugal \\ msantos@direito.uminho.pt \\ http://orcid.org/0000-0001-5996-9850
}

\begin{abstract}
Resumo: A intervenção penal da União Europeia tem sido marcada por um movimento de expansão, de intensificação "acelerada" e de proliferação de instrumentos jurídicos, sobretudo a partir do Tratado de Lisboa, acentuando as lógicas do reconhecimento mútuo, da cooperação e da harmonização. A União Europeia está a um passo de dar início a um exercício transnacional da ação penal, através da publicação do Regulamento (UE) 2017/1939 do Conselho, de 12 de outubro de 2017, que dá execução a uma cooperação reforçada para a instituição da Procuradoria Europeia. Partindo da evolução e das metamorfoses sentidas na intervenção penal na União Europeia, sobretudo a partir do Tratado de Lisboa, que se pretendem dar conta num primeiro momento, pretende-se no presente trabalho sobretudo compreender o sentido e o alcance do Regulamento da Procuradoria Europeia, captando o novo modelo de intervenção penal que se perfilha no horizonte. Estaremos a um passo da integração penal, ou a materialização da Procuradoria Europeia dá apenas mais um passo neste caminho? Qual o seu contributo para um verdadeiro sistema de justiça penal? E neste caminho, deve a Procuradoria Europeia ver o seu âmbito alargado a determinados
\end{abstract}

1 Doutora e mestre pela Escola de Direito da Universidade de Minho/Portugal. Editora-chefe do Journal of Forensic Sciences and Digital Investigation. Professora Auxiliar Convidada na Escola de Direito da Universidade do Minho. 
"crimes graves com dimensão transfronteiriça"?

Palavras-Chave: Intervenção penal da União Europeia; Regulamento da Procuradoria Europeia; novo modelo de intervenção penal.

AвSTRACT: The criminal intervention of the European Union has been marked by a movement of expansion, of intensive acceleration and proliferation of legal instruments, especially since the Treaty of Lisbon, emphasizing the logic of mutual recognition, cooperation and harmonization. The European Union is one step away from initiating a transnational criminal prosecution through the publication of Council Regulation (EU) 2017/1939 of 12 October 2017 implementing enhanced cooperation on the establishment of the European Public Prosecutor's Office ('the EPPO'). On the basis of the evolution and metamorphoses felt in criminal intervention in the European Union, especially since the Treaty of Lisbon, which are intended to give an initial account, the main aim of this work is to understand the meaning and scope of the European Public Prosecutor's Regulation, capturing the new model of criminal intervention that is on the horizon. Are we one step closer to criminal integration, or is the European Public Prosecutor's Office just another step on this path? What is its contribution to a true criminal justice system? And on this path, should the European Public Prosecutor's Office see its scope extended to certain "serious crimes with a cross-border dimension"?

Keywords: Criminal intervention in the European Union; Regulation of the European Public Prosecutor's Office; new model of criminal intervention.

SuMÁRIo: Introdução; 1. A intervenção penal na União Europeia - evolução, metamorfoses e dimensões estruturantes; 2. A implementação da Procuradoria Europeia: um salto na construção de um modelo de integração penal?; 2.1. Da base constante do artigo $86 .^{\circ}$ sobre o TFUE ao texto final do Regulamento da Procuradoria Europeia; 2.2. O Regulamento da Procuradoria Europeia - traços gerais e perspetivas futuras; Considerações Finais; Referências. 


\section{INTRODUÇÃO}

Os tempos atuais têm sido marcados por um movimento de expansão da intervenção penal ${ }^{2}$, circunstância a que o direito penal da União Europeia ${ }^{3}$, sobretudo "em nome da eficácia" ${ }^{4}$, não ficou imune.

Com efeito, o direito penal da União Europeia passou de uma área "livre" de integração a peça fundamental para a criação do espaço de

2 De forma paradigmática sobre o fenómeno da expansão do direito penal nas sociedades pós-industriais, v. SILVA SÁNCHEZ, Jesús-María. La expansión del Derecho Penal, Aspectos de la política criminal en las sociedades postindustriales, $2 .^{\text {a }}$ ed., revista e aumentada. Madrid, Civitas, 2001, especialmente pp. 121 e ss.

3 Para uma descrição do significado doutrinal da expressão “direito penal da União Europeia”, ver, entre outros, já RODRIGUES, Anabela Miranda. O Direito penal Europeu emergente. Coimbra: Coimbra Editora, 2008, p. 14, nota 1. Vd, ainda, MONTE, Mário Ferreira. O Direito Penal Europeu de "Roma" a "Lisboa" - Subsídios Para a Sua Legitimação. Lisboa: Quid Juris Sociedade Editora, 2009, p. 25, nota 3 e do mesmo Autor, O sistema judicial europeu e o controlo jurisdicional em matéria penal: reflexões em torno do direito vigente e do Tratado de Lisboa. IN: ANDRADE, Manuel da Costa, ANTUNES, Maria João, SOUSA, Susana Aires de (org.). Estudos em Homenagem ao Prof. Doutor Jorge de Figueiredo Dias, Vol. I. Coimbra: Coimbra Editora, 2009, p. 736. Refira-se, ainda, que de acordo com a doutrina maioritária não existe um direito penal supranacional da União Europeia com o sentido adotado pelo direito nacional, enquanto, por exemplo, ordenamento jurídico que elabora normas supranacionais de caráter substantivo, processual e executivo de aplicação direta pelos Tribunais, sem a mediação do legislador nacional. Tal como largamente aceite na literatura, o conceito de "direito penal da União Europeia” pretende incluir todas estas “manifestações”, influências do direito da União Europeia no ordenamento jurídico-penal nacional. Além disso, podemos acrescentar, numa visão mais ampla, que a "justiça penal europeia”, e socorrendo-nos da síntese clara de John Vervaele, é uma “... combinação dos sistemas de justiça criminal interna, incluindo os valores constitucionais nacionais, da justiça criminal da União Europeia e também dos elementos de justiça criminal decorrente das Convenções do Conselho da Europa (em matérias substantivas, processuais e de cooperação), em conjunto" - cfr. VERVAELE, John, European Criminal Justice in the global context: challenges and perspectives. In: CAEIRO, Pedro (org.), Proceedings of the conference European criminal law in the global context: values, principles and policies, Coimbra: Instituto Jurídico/ Faculdade de Direito da Universidade de Coimbra, 2017, p. 17.

4 Assim, RODRIGUES, Anabela Miranda. O Direito Penal europeu à luz do princípio da necessidade - o caso do abuso do mercado. Católica Law Review, Volume I, n. ${ }^{\circ}$, nov. 2017, nomeadamente p. 14. 
liberdade, segurança e justiça e para a concretização do próprio projeto de integração da União Europeia.

A evolução da intervenção penal na União Europeia tem sido timbrada pela intensa proliferação de instrumentos jurídicos, permitindo o desenvolvimento das lógicas da cooperação e da harmonização normativa5 .

Além disso, a União Europeia está a um passo de dar início a um exercício transnacional da ação penal, através da publicação do Regulamento (UE) 2017/1939 do Conselho, de 12 de outubro de 2017, que dá execução a uma cooperação reforçada para a instituição da Procuradoria Europeia (Regulamento da Procuradoria Europeia). A implementação de uma Procuradoria Europeia tem sido encarada como uma das questões mais conturbadas no desenvolvimento do direito penal da União Europeia, nos últimos anos ${ }^{6}$, na medida em convoca(rá?) alterações estruturantes na organização e na repartição do poder dos Estados e implica que se questione (com um cenário de intervenção penal mais fundo) a necessidade de uma tutela penal supranacional, aqui voluteando as questões relacionadas com a definição de tipos legais de crime e de sanções criminais, com a promoção de um equilíbrio entre a prossecução penal e a defesa dos direitos fundamentais, com a concretização do espaço de liberdade, segurança e justiça, com o trinómio liberdade, segurança e justiça...7.

O Regulamento da Procuradoria Europeia resulta de um processo longo, marcado por uma negociação jurídico-política difícil, com avanços e recuos. Afigura-se a versão "possível”, numa matéria sensível, e cujo texto não é isento de dúvidas e incertezas, pelo que várias possibilidades se encontram ainda em aberto ${ }^{8}$, em determinados domínios, até porque,

5 Para uma definição dos conceitos de aproximação normativa (através da harmonização, unificação) e de cooperação, que seguimos, v. MORALES ROMERO, Marta Muñoz de. El legislador penal Europeo: legitimidad y racionalidad. Madrid: Editorial Civitas, S.A., 2011, pp. 48 e ss.

6 Ver MITSILEGAS, Valsamis. EU Criminal Law. Oxford: Hart Publishing, 2009, p. 221.

7 Sobre a problemática, ver já o nosso, Para um (novo) modelo de intervenção penal na União Europeia: uma reflexão a partir do princípio da legalidade como limite material de atuação da Procuradoria Europeia. Lisboa, Rei dos Livros, 2016, entres outras, pp. 16 e 17.

8 Ver já a Comunicação da Comissão ao Parlamento Europeu e ao Conselho Europeu - Uma Europa que protege: uma iniciativa destinada a alargar as 
desde logo, o Regulamento da Procuradoria Europeia assenta, em grande medida, nos direitos (substantivo e processual) dos Estados-Membros.

No âmbito do presente trabalho, pretendemos, num primeiro momento, dar conta da evolução e das metamorfoses da intervenção penal na União Europeia, sobretudo a partir do Tratado de Lisboa. Num segundo momento, enquadrado no cenário traçado, pretendemos compreender o sentido e o alcance do Regulamento da Procuradoria Europeia, captando o novo modelo de intervenção penal que se perfilha no horizonte. Estaremos a um passo da integração penal, ou a materialização da Procuradoria Europeia dá apenas mais um passo neste caminho? Qual o seu contributo para um verdadeiro sistema de justiça penal? E neste caminho, deve a Procuradoria Europeia ver o seu âmbito alargado a determinados "crimes graves com dimensão transfronteiriça"?

\section{A intervenção penal na União Europeia - eVolução, METAMORFOSES E DIMENSÕES ESTRUTURANTES}

O direito penal da União Europeia (que inclui a dimensão substantiva, processual e institucional) é uma das áreas da União Europeia

competências da Procuradoria Europeia aos crimes terroristas transnacionais - COM(2018) 641 final (p. 9).

9 Ver novamente a Comunicação da Comissão ao Parlamento Europeu e ao Conselho Europeu - Uma Europa que protege: uma iniciativa destinada a alargar as competências da Procuradoria Europeia aos crimes terroristas transnacionais - COM(2018) 641 final (p. 9). A definição do âmbito material de atuação da Procuradoria Europeia, sobretudo no que diz respeito à proteção dos interesses financeiros da União Europeia, já foi objeto do nosso estudo. Ver, por exemplo, o nosso, O quadro legislativo (substantivo) da Procuradoria Europeia - Algumas reflexões. In: MOTA, Helena et. al. (coord.). XX Estudos Comemorativos dos 20 anos da FDUP, Vol. II. Coimbra: Almedina, 2017 e The definition of the competence ratione materiae of the European Public Prosecutor's Office and the substantive legality principle - the way forward". Portuguese Law Review, N. ${ }^{\circ}$ 0, Vol. 1, Spring 2016, available at http://portugueselawreview.pt/current-issue.html e no nosso Para um (novo) modelo de intervenção penal na União Europeia: uma reflexão a partir do princípio da legalidade como limite material de atuação da Procuradoria Europeia. Lisboa: Rei dos Livros, 2016, entre outras na pp. 233 e ss. No entanto, atendendo à evolução em curso que se tem registado, e a esta iniciativa da Comissão Europeia, o assunto merece um novo olhar. 
que mais tem evoluído ${ }^{10}$. Esta mutação tem igualmente densificado e intensificado os desafios que se colocam ao desenvolvimento da própria União Europeia, da sua relação com os Estados-Membros, bem com os Estados terceiros ${ }^{11}$.

Tal desenvolvimento acentuou-se sobretudo com o Tratado de Lisboa (em seguimento com o grande avanço que se deu com o Tratado de Amesterdão), que representou uma nova fase no processo evolutivo de integração política e jurídica da União Europeia ${ }^{12}$. O Tratado de Lisboa é, pois, encarado como um "marco do ápice da expansão do Direito

10 Para uma compilação dos principais instrumentos jurídicos da União Europeia, ver SANTOS, Margarida. Compilação de Instrumentos Jurídicos de Direito Penal da União Europeia. Braga: Direitos Humanos - Centro de Investigação Interdisciplinar/Escola de Direito da Universidade do Minho, Braga, 2017.

11 Para uma reflexão em torno dos desafios, ver MITSILEGAS, Valsamis, BERGSTRÖM, Maria, KONSTADINIDES, Theodore (ed.). Research handbook on EU Criminal Law, Cheltenham, UK, Northampton, MA, USA: Edward Elgar, 2016, https://doi.org/10.4337/9781783473311, CAEIRO, Pedro (org.). Proceedings of the conference European criminal law in the global context: values, principles and policies. Coimbra: Instituto Jurídico/ Faculdade de Direito da Universidade de Coimbra, 2017 e recentemente CAEIRO, Pedro (ed.). European Criminal Law in the Global Context: Values, Principles and Policies, Special issue of the New Journal of European Criminal Law, março 2019, https:// doi.org/10.1177/2032284419836519, entre outras obras.

12 Com efeito, até ao Tratado de Lisboa ainda se contestava a existência de competências expressas penais por parte da União Europeia. Não obstante, defendia-se largamente na doutrina a existência de certos efeitos do então direito comunitário sobre o direito penal nacional, que se manifestava, sobretudo, à luz de três princípios gerais do direito comunitário: o princípio do efeito direto, o princípio do primado e o princípio da cooperação leal. Além disso, ainda antes da entrada em vigor do Tratado de Lisboa, o Tribunal de Justiça veio em dois Acórdãos (v., especialmente, Acórdão do TJCE, de 13 de setembro de 2005, Comissão v. Concelho Processo N. ${ }^{\circ}$ C-176/03 e Acórdão do TJCE, de 23 de outubro de 2007, Comissão v. Concelho Processo N. ${ }^{\circ} \mathrm{C}-440 / 05$, ambos disponíveis em http://eur-lex.europa.eu/ expressar "alguma competência" da então Comunidade Económica para obrigar os Estados-Membros a utilizarem, entre outras, sanções de natureza penal para repressão das violações de direito comunitário. Para uma análise do desenvolvimento do direito penal da União Europeia, v., entre outra literatura, com muito interesse CAEIRO, Pedro. Reaction to "European Criminal Justice in the global context: challenges and perspectives". In: CAEIRO, Pedro (org.). Proceedings of the conference European criminal law in the global context: values, principles and policies. Coimbra: Instituto Jurídico/ Faculdade de Direito da Universidade de Coimbra, 2017. 
penal europeu" ${ }^{13}$. Com o Tratado de Lisboa, socorrendo-nos das palavras de Pedro Caeiro, "não mais será necessário discutir a titularidade de jurisdição penal por parte da Comunidade Europeia, nem a extensão do âmbito material da jurisdição da União, nem os instrumentos normativos de que ela pode lançar mão para estabelecer regras mínimas relativas à definição das infrações penais e das sanções" ${ }^{14}$.

Numa palavra, o Direito Penal da União Europeia é uma área que se tem intensificado e nessa medida tem estado sob a alçada do olhar político e académico. A este facto acresce a circunstância de ser "estruturalmente e constitucionalmente único" ${ }^{15}$. Nesta medida, atendendo ao volume alcançado em pouco tempo cumpre destacar que está em causa "more of a work in process than a work in progress" ${ }^{16}$.

Não obstante, tem-se refletido sobre a (in)existência de uma verdadeira e autónoma política criminal europeia ${ }^{17}$. Afigura-se pois urgente

13 Cfr. SANTOS, Marina Oliveira Teixeira dos. A expansão do Direito Penal europeu frente à subsidiariedade da tutela penal: alternatividade a partir da Mediação Penal de Adultos portuguesa, Revista Brasileira de Direito Processual Penal, Porto Alegre, vol. 5, n.1, jan-abr, 2019. https://doi.org/10.22197/ rbdpp.v5i1.189, p. 228.

14 Cf. CAEIRO, Pedro. Fundamento, conteúdo e limites da jurisdição penal do Estado - o caso português. Coimbra: Coimbra Editora, 2010, p. 563.

15 MITSILEGAS, Valsamis, BERGSTRÖM, Maria, Konstadinides, THEODORE (ed.). "Introduction”. In: MITSILEGAS, Valsamis, BERGSTRÖM, Maria, KONSTADINIDES, Theodore (ed.). Research handbook on EU Criminal Law. Cheltenham, UK, Northampton, MA, USA: Edward Elgar, 2016, https://doi. org/10.4337/9781783473311, p. 5. Idem, p. 6.

17 Apesar de não existir uma política criminal da União Europeia qua tale, existe, contudo, já uma ordem de valores que fundamenta qualquer modelo de intervenção penal na União Europeia, independentemente do formato, desde logo assente na tutela de bens jurídicos, de interesses fundamentais essenciais para a convivência social nos Estados-Membros e no espaço comum que estes enformam, acabando a União Europeia por ir ensaiando a prática de uma política criminal. Afigura-se, no entanto, essencial uma definição rigorosa e clara dos princípios orientadores de uma política criminal da UE. Para uma proposta dos princípios orientadores da política criminal europeia v. ASP, Petter et. al. Manifiesto sobre la política criminal europea, 2009, p. 727.. A concretização deste "espaço" consiste num "novo" objetivo estabelecido para a União Europeia, pelo Tratado de Amesterdão, e só compreensível pela nova natureza da União como entidade politica que não meramente económica 
diminuir a incerteza jurídica que paira em determinados domínios ${ }^{18}$, traçando-se um rumo mais claro ${ }^{19}$, mais consistente e coerente ${ }^{20}$, que

(Tratado de Maastricht). Nesta medida, vários "marcos" têm-se revelado fundamentais neste caminho, que acompanha "a evolução da integração política que impulsionou igualmente uma maior confiança mútua dos Estados". Assim, v.g., o Programa de Tampere (outubro de 1999), o Programa de Haia (novembro de 2004), o Programa de Estocolmo para o período 2010-2014 (Programa de Estocolmo - Uma Europa aberta e segura que sirva e proteja os cidadãos - 2010/C 115/01), as Conclusões do Conselho Europeu - EUCO 79/14 (junho de 2014), a Agenda Europeia para a Segurança que define as principais medidas para assegurar uma resposta eficaz da União Europeia ao terrorismo e às ameaças contra a segurança da União durante o período 2015-2020 (abril de 2015) e a Agenda Europeia para a Segurança Rumo a uma União de segurança (abril de 2016), entre outros instrumentos, que vão dando "contributos" para a definição de uma política criminal europeia. Com muito interesse ver o Livro Branco da Comissão Europeia sobre o futuro da Europa (White Paper on the future of Europe - Reflections and scenarios for the EU27 by 2025), que nos permite de forma ampla problematizar como deve a União Europeia desenvolver-se nos próximos anos.

Nomeadamente no que diz respeito às opções entre as sanções de natureza administrativa e de natureza criminal. Como refere Anne Weyembergh "a situação atual, em que cabe aos diferentes tribunais decidir sobre a linha divisória precisa entre os dois tipos de sanções, cria um nível muito elevado de incerteza jurídica". Ora, como bem sublinha a Autora, "[a] incerteza que cria parece cada vez mais injustificável, uma vez que a escolha pela natureza administrativa ou criminal das sanções pode ter consequências consideráveis em termos do nível de garantias processuais. Portanto, é urgente refletir sobre como limitar essa incerteza jurídica" (p. 17) - cfr. WEYEMBERGH, Anne. Reaction to "Transforming the ne bis in idem principle into a fundamental right in the EU". In CAEIRO, Pedro (org.). Proceedings of the conference European criminal law in the global context: values, principles and policies. Coimbra: Instituto Jurídico/ Faculdade de Direito da Universidade de Coimbra, 2017, p. 42. Ver também CAEIRO, Pedro. The influence of the EU on the 'blurring' between administrative and criminal law". In: GALLI, Francesca, WEYEMBERGH, Anne. Do Labels still Matter? Blurring Boundaries between Administrative and Criminal Law. The Influence of the EU. Bruxelles: Ed. Univ. Bruxelles, 2014, p. 175.

19 Aliás, das diferenças de perspetivas das várias instâncias da União Europeia dá-nos conta Rodrigues, Anabela Miranda. Direito Penal Económico: uma política criminal na era compliance. Coimbra: Almedina, 2019, pp. 90/91, onde se sublinha que a visão do Conselho Europeu (por exemplo olhando para o programa de Estocolmo) se aproxima da visão funcionalista da Comissão, enquanto o Conselho e o Parlamento Europeu sublinham os limites da intervenção penal. 
"aspir[e] a um nível mais elevado de racionalidade e po[ssa] servir de inspiração para um modelo global”21.

Porventura afigura-se uma pretensão difícil de alcançar atendendo, por um lado, às próprias características (únicas) da União Europeia e às encruzilhadas e indefinições que enfrenta ${ }^{22} \mathrm{e}$, por outro, aos desafios e contradições que o paradigma político, social e económico da

Committee and the Committee of the Regions - Towards an EU Criminal Policy: Ensuring the effective implementation of EU policies through criminal law, p. 3: “...it is particularly important to ensure that EU legislation on criminal law, in order to have a real added value, is consistent and coherent".

21 A expressão, ainda que em tom indagatório, é de CAEIRO, Pedro. Reaction to "European Criminal Justice in the global context: challenges and perspectives". In: CAEIRO, Pedro (org.). Proceedings of the conference European criminal law in the global context: values, principles and policies. Coimbra: Instituto Jurídico/ Faculdade de Direito da Universidade de Coimbra, 2017, p. 22. Na verdade, como bem reflete Anabela Miranda Rodrigues, "as ameaças, as incertezas e a instabilidade - as crises" revelam as "vulnerabilidades e as dificuldades que [os Estados] enfrentam em lidar com as questões político-criminais", permitindo compreender que "a crença na eficácia da política criminal estadual está abalada" - cfr. Rodrigues, Anabela Miranda. Direito Penal Económico: uma política criminal na era compliance. Coimbra: Almedina, 2019, p. 17.

${ }^{22}$ Como de forma expressiva refere Helmut Satzger saber se é objetivo futuro da União Europeia alcançar, por exemplo, um maior grau de desenvolvimento do reconhecimento mútuo (convergindo para a sua forma pura) afigura-se algo que só poderá ser respondido quando a própria União Europeia "for capaz de definir o que o seu objetivo deve ser: um Estado federal, uma forma solta da confederação ou algo entre eles”. Ademais, como sublinha o Autor, "[e]specialmente nos dias de hoje - com o Brexit, governos antieuropeus no poder em alguns Estados-Membros e a ascensão de partidos nacionalistas em muitos países da Europa - está longe de ser claro onde a trajetória da União pode levar" - SATZGER, Helmut. Is mutual recognition a viable general path for cooperation? (commented structure and conclusion-draft). In: CAEIRO, Pedro (org.). Proceedings of the conference European criminal law in the global context: values, principles and policies. Coimbra: Instituto Jurídico/ Faculdade de Direito da Universidade de Coimbra, 2017, p. 46. 
pós-modernidade revela ${ }^{23}$, onde "a globalização é hoje o novo paradigma da política criminal" ${ }^{4}$.

De resto, um dos traços do direito penal europeu é a sua "mutabilidade", quanto "às estruturas em que assenta e aos mecanismos por meio dos quais opera" 25 .

Neste contexto de transmutação cumpre apreender que tem existindo "uma nova linha de intervenção da UE em matéria penal" - inaugurada com o Tratado de Lisboa e sobretudo com a adoção do Roteiro para o reforço dos direitos processuais dos suspeitos ou acusados em processos penais pelo Conselho em $2009^{26}$ e das diretivas que se lhe seguiram ${ }^{27}$ - que

23 Na verdade, vivemos tempos marcados, por um lado, pelo progresso científico e bem-estar social, mas, por outro, pela indeterminação, pela efemeridade, pela insegurança, pelo risco. Sobre estas contradições, que se fazem igualmente sentir na seara penal, ver, entre outros, DELMAS-MARTY, Mireille. Les contradictions du droit pénal. Revue de science criminelle et de droit pénal comparé, n. ${ }^{\circ}$ 1, 2000, p. 3 e SILVA SANCHEZ, Jesús-María. La expansión del Derecho Penal, Aspectos de la política criminal en las sociedades postindustriales, 2. ${ }^{\mathrm{a}}$ ed., revista e aumentada. Madrid: Civitas, 2001, pp. 41 e 42.

RODRIGUES, Anabela Miranda e MOTA, José Luís Lopes da. Para uma Política Criminal Europeia. Quadro e instrumentos jurídicos da cooperação judiciária em matéria penal no espaço da União Europeia. Coimbra: Coimbra Editora, 2002, p. 13. Para uma caraterização da problemática da globalização sobre o direito penal, v., já, entre outra literatura, entre nós, v.g., DIAS, Jorge de Figueiredo. O direito penal entre a 'sociedade industrial' e a "sociedade do risco". In: Estudos em Homenagem ao Prof. Doutor Rogério Soares. Coimbra: Coimbra Editora, 2001 e Rodrigues, Anabela Miranda. Direito penal económico - é legítimo? é necessário?.Revista Portuguesa de Ciência Criminal, Ano 26, 2016, pp. 42 e ss. Paradigmaticamente, sobre a "sociedade do risco" introduzida por Beck, $v d$. (além de outras obras que se seguiram do Autor), BECK, Ulrich, Risikogesellschaft. Auf dem Weg in eine andere Moderne. Frankfurt a.M.: Suhrkamp, 1986.

CAEIRO, Pedro. Reconhecimento mútuo, harmonização e confiança mútua (primeiro esboço de uma revisão). In: SANTOS, Margarida, MONTE, Mário Ferreira e MONTEIRO, Fernando Conde (coord.). Os novos desafios da cooperação judiciária e policial na União Europeia e da implementação da Procuradoria Europeia. Braga: Centro de Investigação Interdisciplinar em Direitos Humanos/Escola de Direito da Universidade do Minho, 2017, p. 35.

Resolução do Conselho de 30 de Novembro de 2009 sobre um Roteiro para o reforço dos direitos processuais dos suspeitos ou acusados em processos penais - 2009/C 295/01.

27 Cf.: Diretiva 2010/64/UE do Parlamento Europeu e do Conselho, de 20.10, relativa ao direito à interpretação e tradução em processo penal, de 26.10; Diretiva 2011/36/UE do Parlamento Europeu e do Conselho de 5.04 relativa 
visa "assegurar um «melhor equilíbrio» entre esse direitos [individuais] e as «medidas que visam facilitar a instauração de processos penais»" e que extravasa "do conteúdo clássico da «conexão europeia», assentando decididamente em fundamentos jurídico-axiológicos autónomos”28.

Com efeito, a intervenção da União Europeia foi-se pautando sobretudo pela máxima de fortalecer o sistema punitivo dos EstadosMembros, em linha com o formato com que os Estados-Membros foram edificando a jurisdição penal da União Europeia, assente sobretudo no aumento da cooperação, onde se produziram mecanismos de cooperação intrinsecamente europeus, como o reconhecimento mútuo, e na harmonização/aproximação normativa de cariz substantivo, impondo-lhes deveres de incriminar certas condutas e de estabelecer sanções mínimas para as mesmas ${ }^{29}$. Surgiu, depois, a necessidade de salvaguardar os direitos dos participantes processuais envolvidos. Numa palavra, é a existência de um verdadeiro sistema de justiça criminal da União Europeia que vai

à prevenção e luta contra o tráfico de seres humanos e à protecção das vítimas; Diretiva 2012/13/UE do Parlamento Europeu e do Conselho de 22.05 relativa ao direito à informação em processo penal; Diretiva 2012/29/UE do Parlamento Europeu e do Conselho, de 25.10, que estabelece normas mínimas relativas aos direitos, ao apoio e à proteção das vítimas da criminalidade; Diretiva 2013/48/UE do Parlamento Europeu e do Conselho, de 22.10, relativa ao direito de acesso a um advogado em processo penal e nos processos de execução de mandados de detenção europeus, e ao direito de informar um terceiro aquando da privação de liberdade e de comunicar, numa situação de privação de liberdade, com terceiros e com as autoridades consulares. Diretiva (UE) 2016/343 do Parlamento Europeu e do Conselho de 9 de março de 2016 relativa ao reforço de certos aspetos da presunção de inocência e do direito de comparecer em julgamento em processo penal. Diretiva (UE) 2016/800 do Parlamento Europeu e do Conselho, de 11 de maio de 2016, relativa a garantias processuais para os menores suspeitos ou arguidos em processo penal. Diretiva (UE) 2016/1919 do Parlamento Europeu e do Conselho, de 26 de outubro de 2016, relativa ao apoio judiciário para suspeitos e arguidos em processo penal e para as pessoas procuradas em processos de execução de mandados de detenção europeus.

28 Assim, CAEIRO, Pedro.Introdução (ou de como todo o processo penal começa com uma constituição de direitos). In: CAEIRO, Pedro (org.). A Agenda da União Europeia sobre os Direitos e Garantias da Defesa em Processo Penal: a "segunda vaga" e o seu previsivel impacto sobre o direito português. Coimbra: Instituto Jurídico/Faculdade de Direito da Universidade de Coimbra, 2015, p. 10. Idem, pp. 7. e 8. 
ganhando espaço. Ou nas palavras claras de Anabela Miranda Rodrigues, "[e]ste é o tempo de o direito penal europeu dar sinais inequívocos de que está ao serviço do arguido, da vítima e do condenado. E, assim, de se construir, não como um ordenamento de segurança, mas como um ordenamento de liberdade" ${ }^{30}$.

Por fim, importa ainda sublinhar, "no quadro penal", no contexto do espaço de liberdade, segurança e justiça, as grandes vertentes estruturantes, que têm permanecido, embora com intensidades e ritmos diferentes: a harmonização (substantiva e processual); a cooperação horizontal (assente sobretudo no reconhecimento mútuo); o desenvolvimento de agências europeias de execução (de atores judiciários) e a dimensão externa do espaço de liberdade, segurança e justiça ${ }^{31}$.

Um apontamento ainda de enquadramento é devido para deixar claras as bases normativas do direito penal da União Europeia, que permitem a apreensão do "quadro penal", ainda que de forma sincopada ${ }^{32}$.

A base jurídica para a harmonização do direito penal substantivo (através de diretivas) está contida no art. ${ }^{\circ} 83 .^{\circ}$, do Tratado sobre o Funcionamento da União Europeia (TFUE), sobretudo ${ }^{33}$. De acordo com o

30 RODRIGUES, Anabela Miranda, Direito penal europeu pós-Lisboa - um direito penal funcionalista?.In: SANTOS, Margarida, MONTE, Mário Ferreira e MONTEIRO, Fernando Conde (coord.). Os novos desafios da cooperação judiciária e policial na União Europeia e da implementação da Procuradoria Europeia. Braga: Centro de Investigação Interdisciplinar em Direitos Humanos/ Escola de Direito da Universidade do Minho, 2017, p. 33 (artigo igualmente publicado na Revista de Legislação e Jurisprudência, Ano $146^{\circ}, \mathrm{n}^{\circ} 4004$, Julho -Agosto, 2017, pp.320-334).

31 Ver VERVAELE, John. European Criminal Justice in the global context: challenges and perspectives. In: CAEIRO, Pedro (org.). Proceedings of the conference European criminal law in the global context: values, principles and policies. Coimbra: Instituto Jurídico/ Faculdade de Direito da Universidade de Coimbra, 2017, p. 17.

32 Para maiores desenvolvimentos ver o nosso Para um (novo) modelo de intervenção penal na União Europeia: uma reflexão a partir do princípio da legalidade como limite material de atuação da Procuradoria Europeia, Lisboa, Rei dos Livros, 2016, pp. 171 e ss.

33 Ademais, existe uma outra norma relevante "fora" deste espaço normativo: o art. $^{\circ} 325$. ${ }^{\circ}$, do TFUE, incluído no Capítulo 6 ("A luta contra a fraude"), do Título II do TFUE ("Disposições financeiras"), da Parte VI ("Disposições institucionais e financeiras"). Nos termos do disposto no $\operatorname{art}^{\circ} 325 .^{\circ}$, n. $^{\circ} 1$, 
do TFUE, a UE e os Estados-Membros combaterão as fraudes lesivas dos interesses financeiros da União, por meio de medidas que tenham um efeito dissuasor e proporcionem uma proteção efetiva nos Estados-Membros, bem como nas instituições, órgãos e organismos da União. Este artigo, como reflete Paulo de Sousa Mendes, não impõe qualquer obrigação ao EstadoMembro de criar infrações penais para tutela dos interesses financeiros da União, mas prevê o princípio da assimilação, de acordo com o qual os Estados-Membros são obrigados, nos termos do n. ${ }^{\circ}$ 2, do art. ${ }^{\circ} 325 .^{\circ}$, do TFUE, a "tomar medidas análogas às que tomarem para combater as fraudes lesivas dos seus próprios interesses financeiros" - cfr. MENDES, Paulo de Sousa. Comentário ao art. ${ }^{\circ} 325^{\circ}$. $^{\circ}$ In: PORTO, Manuel Lopes, ANASTÁCIO, Gonçalo (coord.), Tratado de Lisboa Anotado e Comentado. Coimbra: Almedina, 2012, p. 1146. Nos termos do art. ${ }^{\circ} 325 .^{\circ}$, n. ${ }^{\circ}$ 4, do TFUE, “[o] Parlamento Europeu e o Conselho deliberando de acordo com o processo legislativo ordinário e após consulta ao Tribunal de Contas, adotarão as medidas necessárias nos domínios da prevenção e combate das fraudes lesivas dos interesses financeiros da União, tendo em vista proporcionar uma protecção efectiva e equivalente nos Estados-Membros, bem como nas instituições, órgãos e organismos da União". Neste medida, as obrigações expressas de incriminação dirigidas aos Estados-Membros, visando a aproximação dos respetivos direitos internos decorrem de Convenções e Protocolos (adotados pelo método intergovernamental, no âmbito do antigo Terceiro Pilar) e de diretivas. Parece ser de entender que com a luz do Tratado de Lisboa, rectius com a omissão produzida, tanto as diretivas como os regulamentos poderão ser adotados neste âmbito. Grande parte da literatura perspetiva o art. ${ }^{\circ} 325 .^{\circ}$, do TFUE como specialis relativamente ao generalis art. ${ }^{\circ} 83 .^{\circ}$, n. $^{\circ}$ 1 e 2 , do TFUE. Aliás, o art. $^{\circ} 325^{\circ}$, do TFUE acaba por excluir as "desvantagens institucionais" atribuídas ao art. ${ }^{\circ} 83 .^{\circ}$, n. ${ }^{\circ} 1$ e 2 , do TFUE. Na esteira de grande parte da doutrina, houve, na verdade, uma alteração (omissão) significativa no texto do artigo $325^{\circ}$, do TFUE (anterior artigo $280^{\circ}$, do TCE), que se refere à luta contra a fraude e quaisquer outras atividades ilegais lesivas dos interesses financeiros da União. Além disso, alguma literatura (minoritária) entende também que o art. ${ }^{\circ} 86 .^{\circ}$, do TFUE poderá servir de base para a aproximação normativa no âmbito da concretização das competências materiais da Procuradoria Europeia. Neste sentido, há três soluções possíveis para proceder à aproximação normativa no que toca à concretização do âmbito ("amplo") de atuação da Procuradoria Europeia: (i) o art.o 83. ${ }^{\circ}$, de acordo com o qual se poderia, pelo menos em teoria, "aproximar" através de diretivas; (ii) o art. $^{\circ} 86 .^{\circ}$, n. ${ }^{\circ} 1$, n. ${ }^{\circ} 2$ e n. ${ }^{\circ} 4$ do TFUE e (iii) o art. ${ }^{\circ} 325 .^{\circ}$, n. ${ }^{\circ} 4$ do TFUE. Defendendo, com base no art. ${ }^{\circ} 86 .^{\circ}$, a utilização do regulamento para definir o âmbito de atuação material da Procuradoria Europeia, v., entre outra literatura, com a qual nos identificamos, LIGETI, Katalin. Approximation of substantive criminal and the establishment of the European Public Prosecutor's Office. In GALLI, Francesca, WEYEMBERG, Anne (Ed.). Approximation of substantive criminal law in the EU - The way forward. Belgium: Editions de 1'Université de Bruxelles, 2013 e Para um 
parágrafo 1, do n. ${ }^{0}$ 1, deste artigo, o Parlamento Europeu e o Conselho podem estabelecer regras mínimas relativas à definição de infrações penais e das sanções em domínios de criminalidade particularmente grave com dimensão transfronteiriça, se isso for necessário ( art. $^{\circ} 67 .^{\circ}$, n. ${ }^{\circ} 3$, do TFUE) $)^{34}$.

Além disso, o art. ${ }^{\circ} .83 .^{\circ}$, n. $^{\circ}$ 2, do TFUE contém uma base jurídica para a harmonização de regras mínimas relativas à definição das infrações penais e das sanções no domínio em causa, desde que se afigure indispensável para assegurar a implementação eficaz de uma política da União num domínio que tenha sido objeto de medidas de harmonização ${ }^{35}$.

Quanto ao direito processual penal, estas regras mínimas deverão ser adotadas nas áreas contempladas no art. $^{\circ} 82^{\circ} \mathrm{n} .{ }^{\circ} 2$ : (i) a admissibilidade mútua dos meios de prova entre os Estados Membros; (ii) os direitos individuais em processo penal; (iii) os direitos das vítimas da criminalidade; (iv) outros elementos específicos do processo penal, identificados previamente pelo Conselho através de uma decisão.

A pedra angular de todos os atos jurídicos que servem para implementar essa ideia é o princípio do reconhecimento mútuo ${ }^{36}$, que,

(novo) modelo de intervenção penal na União Europeia: uma reflexão a partir do princípio da legalidade como limite material de atuação da Procuradoria Europeia, Lisboa, Rei dos Livros, 2016, entre outras na pp. 318 e ss.

${ }_{34}$ As áreas relevantes constam do art. $83 .^{\circ}, \mathrm{n}$. os 1 e 2: terrorismo, tráfico de seres humanos e a exploração sexual de mulheres e crianças, tráfico ilícito de drogas, tráfico de armas, branqueamento de capitais, corrupção, contrafação de meios de pagamento, criminalidade informática e crime organizado. No entanto, de acordo com o disposto no n..$^{\circ} 1$ do art. $^{\circ} 83 .^{\circ}$, do TFUE, o Conselho, tendo em conta a evolução da criminalidade, poderá, por decisão unânime, após aprovação do Parlamento Europeu, adotar uma decisão que identifique outros domínios da criminalidade e, assim, ampliar o catálogo descrito.

35 Esta harmonização mínima é limitada pelo "travão de emergência" contemplado no art. $83 .^{\circ}$, n. $^{\circ} 3$, do TFUE. Nesta medida, se um Estado-Membro considerar que uma diretiva afeta aspetos fundamentais do seu sistema de justiça penal, pode solicitar que esse projeto seja submetido ao Conselho Europeu, ficando suspenso o processo legislativo ordinário. De resto, se não for atingido consenso político, pelo menos nove Estados-membros poderão estabelecer uma "cooperação reforçada" com base no projeto de diretiva em causa.

36 Para uma análise da evolução da compreensão do reconhecimento mútuo, sobretudo à luz da jurisprudência do Tribunal de Justiça da União Europeia ver já CAEIRO, Pedro, FIDALGO, Sónia e RODRIGUES, João Prata.The 
após o Tratado de Lisboa está contemplado por escrito no art. $82 .^{\circ}$, do TFUE. Nesta medida, em primeiro lugar, no . $^{\circ} 1$, do art. ${ }^{\circ} 82 .^{\circ}$, do TFUE estabelece-se o princípio do reconhecimento mútuo como princípio base da cooperação judiciária em matéria penal na União (ou pedra angular como proclamado na conclusão 33 no Conselho Europeu de Tampere mas só obteve consagração expressa no Tratado de Lisboa).

O princípio do reconhecimento mútuo pois é complementado com a aproximação normativa nos domínios a que se refere o $\mathrm{n} .{ }^{\circ} 2$ do art. $^{\circ} 82 .^{\circ}$ e o art. $^{\circ} 83$, do TFUE, que apenas assume relevância se se demonstrar insuficiente a ação dos Estados-Membros a nível nacional, como, de resto, é pressuposto geral de toda a atuação da União Europeia.

Na leitura do art. $^{\circ} 82 .^{\circ}$, do TFUE devem distinguir-se duas formas de atuação alternativas: a do n. ${ }^{\circ} 1$ e a do n. ${ }^{\circ}$ 2, embora a interpretação destes dois preceitos tenha de ser conjugada.

Nos termos do contemplado no n. ${ }^{\circ} 1$, do art. $^{\circ} 82 .^{\circ}$, do TFUE, a União Europeia deverá adotar, com base no princípio do reconhecimento mútuo ou para assegurar a efetividade deste - medidas relativas a: "regras e procedimentos para assegurar o reconhecimento em toda a EU de todas as formas de sentenças e decisões judiciais; prevenir e resolver os conflitos de jurisdição, etc. (sc., fazendo uso de qualquer dos instrumentos jurídicos à disposição porque o Tratado não define o instrumento a utilizar - e.g., a diretivas, o regulamento, ou a decisão) ${ }^{37}$.

O n. ${ }^{\circ}$ 2, do art. ${ }^{\circ} 82 .^{\circ}$, do TFUE fornece a base jurídica expressa para a aproximação em matéria de direito processual penal, sendo uma

evolving notion of mutual recognition in the CJEU's case law on detention. Maastricht Journal of European and Comparative Law, Vol. 25, n. ${ }^{\circ}$ 6. DOI: 10.1177/1023263X18822787, pp. 689-703, 2019 e CAEIRO, Pedro. Reconhecimento mútuo, harmonização e confiança mútua (primeiro esboço de uma revisão). In: SANTOS, Margarida, MONTE, Mário Ferreira e MONTEIRO, Fernando Conde (coord.). Os novos desafios da cooperação judiciária e policial na União Europeia e da implementação da Procuradoria Europeia. Braga: Centro de Investigação Interdisciplinar em Direitos Humanos/Escola de Direito da Universidade do Minho, 2017, p. 35.

37 Para uma definição clara dos conceitos de aproximação normativa (através da harmonização, unificação) e de cooperação, v. MORALES ROMERO, Marta Muñoz de. El legislador penal Europeo: legitimidade y racionalidade. Madrid: Editorial Civitas, S.A., 2011, pp. 48 e ss. 
inovação do Tratado de Lisboa que vem encerrar a discussão sobre a base jurídica da aproximação (apenas através da harmonização) neste domínio ${ }^{38}$.

A nível institucional, refira-se, ainda, que tem havido um desenvolvimento de organismos que complementam a atuação das estruturas nacionais que têm a seu cargo a investigação, o exercício da ação penal e o julgamento do facto penal. Em especial, entre outros atores judiciários, cumpre referir a Eurojust - art. $^{\circ} 85$ $^{\circ}$, do TFUE ${ }^{39}$ e o Serviço Europeu de Polícia (Europol) - art. ${ }^{\text {ss }} 87$ e ss $^{40}$. Permite-se, nesta sede, a criação de uma Procuradoria Europeia, cuja possibilidade encontra-se no art. ${ }^{\circ} 86 .{ }^{\circ}$, do TFUE, como a seguir daremos conta.

Observa-se, face ao exposto, uma harmonização normativa mais intensa, uma cooperação acentuada e um caminho para uma maior integração. Atendendo à linha seguida no âmbito da "cooperação horizontal" entre as autoridades dos Estados-Membros, assente em mecanismos de cooperação, passando pela "cooperação vertical", através, v.g., da intervenção da Eurojust, importa captar os contornos do modelo encetado

${ }^{38}$ Neste sentido, uma leitura conjunta desta norma com a do art. ${ }^{\circ} 67$, n. ${ }^{\circ} 3$ do TFUE conduz à limitação do recurso à harmonização aos casos em que esta seja "necessária" e não apenas "conveniente" ao estabelecimento do princípio do reconhecimento mútuo, como poderia parecer indicar a utilização da palavra "facilitar" no art. ${ }^{\circ} 82 .^{\circ},{ }^{\circ}{ }^{\circ} 2$ do TFUE.

A Eurojust foi criada pela Decisão 2002/187/JAI do Conselho, com o objetivo de estimular e melhorar a coordenação e a cooperação entre as autoridades judiciárias competentes dos Estados-Membros, nomeadamente em relação a formas graves de criminalidade organizada. O regime jurídico da Eurojust foi alterado pelas Decisões 2003/659/JAI e 2009/426/JAI do Conselho. Recentemento, depois de uma longa negociação, foi publicado o novo quadro jurídico da Eurojust: Regulamento (UE) 2018/1727 do Parlamento Europeu e do Conselho de 14 de novembro de 2018 que cria a Agência da União Europeia para a Cooperação Judiciária Penal (Eurojust), e que substitui e revoga a Decisão 2002/187/JAI do Conselho.

40 A Europol foi inicialmente criada com base na Convenção Europol, de 1995, que foi substituída pela Decisão 2009/371/JAI do Conselho. Esta decisão foi substituída (desde 1 de maio de 2017) pelo Regulamento (UE) 2016/794 do Parlamento Europeu e do Conselho, de 11 de maio de 2016, que cria a Agência da União Europeia para a Cooperação Policial (Europol) e que substitui e revoga as Decisões 2009/371/JAI, 2009/934/JAI, 2009/935/JAI, 2009/936/ JAI e 2009/968/JAI do Conselho. 
pela Procuradoria Europeia, que extravasa a lógica da cooperação ${ }^{41}$. As vias foram, pois, abertas...

\section{A implementação da Procuradoria Europeia: um salto na CONSTRUÇÃO DE UM MODELO DE INTEGRAÇÃO PENAL?}

\subsection{DA BASE CONSTANTE DO ARTIGO $86^{\circ}$ SOBRE O TFUE AO TEXTO FINAL do Regulamento da Procuradoria Europeia}

A aspiração relacionada com a conceção de uma Procuradoria Europeia não é recente, estando a sua origem relacionada com a necessidade de se promover um sistema adequado para a proteção dos interesses financeiros das Comunidades Europeias ${ }^{42}$.

41 Ver o nosso Para um (novo) modelo de intervenção penal na União Europeia: uma reflexão a partir do princípio da legalidade como limite material de atuação da Procuradoria Europeia. Lisboa: Rei dos Livros, 2016, entre outras na p. 191.

42 A primeira proposta concreta surge em 1997, através de um grupo de peritos sob a direção de Mireille Delmas-Marty, que apresentou, a pedido da Comissão e do Parlamento Europeu, o projeto de Corpus Juris relativo às disposições penais sobre a proteção dos interesses financeiros da Comunidade. $\mathrm{O}$ projeto de Corpus Juris foi objeto de duas versões: uma em 1997 e outra em 2000 - DELMAS-MARTY, Mireille (Dir.), Corpus Juris relativo às disposições penais para a protecção dos interesses financeiros da União Europeia. Paris: Economica, 1997 e DELMAS-MARTY, Mireille, VERVAELE, J. A. E. A aplicação do Corpus Juris nos Estados-Membros. Utrecht: Intersentia, 4 Vol., 2000. Posteriormente, a ideia foi retomada por um Comité de Peritos independentes designado pelo Parlamento Europeu, em sequência de acusações de fraude feitas à Comissão. Por ocasião da Conferência Intergovernamental de Nice, a Comissão apresentou uma proposta relativa à criação de um Procurador Europeu no domínio da proteção dos interesses financeiros comunitários (Comunicação da Comissão de 29 de Setembro de 2000 relativa à proteção penal dos interesses financeiros comunitários: um Procurador Europeu - COM(2000) 608 final) que não foi, no entanto, adotada. Em 2001, a Comissão apresenta o Livro Verde sobre a proteção penal dos interesses financeiros comunitários e a criação de um Procurador Europeu, com uma abordagem diferente, assente no princípio do reconhecimento mútuo, tendo apresentado, 2003, um Relatório de Acompanhamento - Follow-up report on the Green Paper on the criminal-law protection of the financial interests of the Community and the establishment of a European Prosecutor - COM (2003) 128 final. No Tratado que estabelece uma Constituição para a Europa, surge a possibilidade de criação de uma Procuradoria Europeia, nos termos do art. ${ }^{\circ}$ III-274. ${ }^{\circ}$. Para maiores 


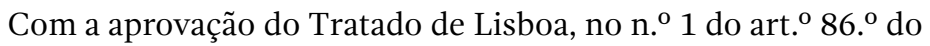
TFUE, foi finalmente expressamente inserida uma base jurídica para a instituição de uma Procuradoria Europeia no rrt. $^{\circ} 86 .^{\circ}$ do TFUE, remetendo-se a definição da sua estrutura e das funções para um regulamento.

No n. ${ }^{\circ} 1$ do art. $^{\circ} 86 .^{\circ}$ do TFUE, estabelece-se a possibilidade de o Conselho criar uma Procuradoria Europeia a partir da Eurojust. O n. ${ }^{\circ} 2$ deste artigo "define" o âmbito material de atuação da Procuradoria Europeia: "infrações lesivas dos interesses financeiros da União" contempladas no n. ${ }^{\circ} 1$, prevendo-se, nos termos do n. ${ }^{\circ} 4$ deste artigo, a possibilidade de o Conselho estender o âmbito de competência material da Procuradoria ao combate à "criminalidade grave com dimensão transfronteiriça". Esta decisão pode ser simultânea ou posterior à criação da Procuradoria e será adotada por unanimidade do Conselho, após aprovação do Parlamento e consulta à Comissão.

Como já noutro escrito apontámos, o art. $^{\circ} 86 .^{\circ}$ do TFUE abarcou, de certa forma, os dois domínios de criminalidade, sintetizando os dois entendimentos existentes acerca da "mais-valia" da Procuradoria Europeia $^{43}$.

desenvolvimentos, ver o nosso, Para um (novo) modelo de intervenção penal na União Europeia: uma reflexão a partir do princípio da legalidade como limite material de atuação da Procuradoria Europeia. Lisboa: Rei dos Livros, 2016 pp. 225 e ss. Sobre a criação de uma Procuradoria Europeia, ver, já, entre outros, GEELHOED, Willem, ERKELENS, Leendert Hendrik, MEIJ, Arjen (Eds.). Shifting Perspectives on the European Public Prosecutor's Office, T.M.C. The Hague: Asser Press, 2018; WEYEMBERGH, Anne, BRIÈRE, Chloé. Towards a European Public Prosecutor's Office (EPPO), Study for the Libe Committee. European Parliament, 2016.

43 Ver o nosso Para um (novo) modelo de intervenção penal na União Europeia: uma reflexão a partir do princípio da legalidade como limite material de atuação da Procuradoria Europeia, Lisboa, Rei dos Livros, 2016, pp. 294 e ss. Ver LIGETI, Katalin. Approximation of substantive criminal and the establishment of the European Public Prosecutor's Office. In GALLI, Francesca, WEYEMBERG, Anne (Ed.). Approximation of substantive criminal law in the EU - The way forward. Belgium: Editions de l'Université de Bruxelles, 2013, pp. 75 e 76. Com efeito, enquanto, v.g., uns Estados-Membros pretendiam apenas reforçar os mecanismos de prossecução quanto às ofensas contra os interesses financeiros da União Europeia, vendo a Procuradoria Europeia como "um serviço especializado" com um âmbito de atuação restrito apenas às ofensas que afetem, grosso modo, o orçamento da União Europeia, outros entendiam que se deveria ir mais além, vendo a 
Na esteira do n. ${ }^{\circ} 3$ do art. ${ }^{\circ} 86 .^{\circ}$ do TFUE, o regulamento definirá as condições em que a Procuradoria Europeia exerce as suas funções, as regras processuais aplicáveis às suas atividades e as que regem a admissibilidade dos meios de prova, bem como as regras aplicáveis à fiscalização jurisdicional dos atos da Procuradoria Europeia.

Nesta medida, "[o] texto do art. ${ }^{\circ} 86 .^{\circ}$ do TFUE, na sua ambiguidade e dependendo da interpretação que se colha, parece dar margem para que se desenvolvam «diferentes» modelos de intervenção penal na UE"44.

Em 17 de julho de 2013, a Comissão adotou uma Proposta de Regulamento do Conselho que institui a Procuradoria Europeia ${ }^{45}$.

A opção tomada pela Comissão Europeia em 17 de julho de 2013 em cingir-se, pelo menos num primeiro momento, à proteção dos interesses financeiros transparece a necessidade de obtenção de consenso político, face aos argumentos existentes, de diferentes quadrantes (políticos, académicos, da praxis judiciária,... $)^{46}$, que acabam por espelhar a vontade de manutenção do exercício da ação penal no foro nacional. A par disso, a própria Comissão Europeia foi "justificando" a opção com base na necessidade de se ser promovida uma verdadeira "democracia económica" ${ }^{77}$.

Procuradoria Europeia num contexto mais amplo, no âmbito da construção de um espaço de liberdade, segurança e justiça, importante para combater a criminalidade grave transfronteiriça ou organizada.

44 Cfr. o nosso, para onde remetemos para maiores desenvolvimentos, Para um (novo) modelo de intervenção penal na União Europeia: uma reflexão a partir do princípio da legalidade como limite material de atuação da Procuradoria Europeia. Lisboa: Rei dos Livros, 2016, p. 234.

45 Proposta de Regulamento do Conselho que institui a Procuradoria Europeia $\operatorname{COM}(2013) 534$ final.

46 A este propósito, v. o estudo baseado nos inquéritos realizados a práticos judiciários nacionais e da UE - WADE, Marianne (coord.). EuroNEEDs, Evaluating the need for and the needs of a European Criminal Justice System. Max-Planck-Institute für ausländisces und internationales Strafrecht, Preliminary report, 2011 e WADE, Marianne. A European public prosecutor: potential and pitfalls. Crime Law Soc Change, mar., 2013.

47 Cf. SANTOS, Margarida. A Procuradoria Europeia, a democracia económica e a ação penal dos crimes que lesem os interesses financeiros da União Europeia. In: CARVALHO, Maria Miguel, MESSA, Ana Flávia, NOHARA, Irene Patrícia (coord.). Democracia Económica e Responsabilidade Social nas Sociedades Tecnológicas. Braga: Escola de Direito da Universidade do Minho, ebook, 2019, p. 190. Ver, a título de exemplo, a Exposição de Motivos constante da Proposta de 
Após um intenso debate, com avanços e recuos, onde inexistiu unanimidade, foi publicado, em 31 de outubro de 2017, o Regulamento da Procuradoria Europeia.

Podemos já adiantar, como já noutro escrito acentuámos, que, comparando com a versão (inicial) apresentada pela Comissão Europeia com o texto do Regulamento, verifica-se "uma limitação da ambição de integração, inexistindo a verdadeira revolução preconizada na Proposta elaborada pela Comissão em 2013. Com efeito, assistiu-se a uma mudança da própria estrutura da Procuradoria Europeia e a uma redução dos instrumentos e medidas de investigação constantes da inicial proposta, que nos fazem questionar a eficácia da Procuradoria Europeia no exercício da ação penal relativamente aos crimes que lesem os interesses financeiros da UE"48.

O Regulamento da Procuradoria Europeia foi publicado no dia 31 de outubro de 2017 e entrou em vigor em 20 de novembro de 2017, já com a participação de vinte Estados-Membros ${ }^{49}$, a que, entretanto se juntaram mais dois ${ }^{50}$. Tem sido apontado o ano de 2020 como meta a alcançar para a "atuação plena" da Procuradoria Europeia, estando em

Regulamento do Conselho que institui a Procuradoria Europeia - COM(2013) 534 final, onde se justifica a necessidade de prevenção e repressão dos crimes que lesam os interesses financeiros da União Europeia, num período de consolidação orçamental. Ver também, neste sentido, CSONKA, Peter. General presentation of the proposal and main issues: the state of negotiations, solutions reached and main issues to be resolved, In: SANTOS, Margarida, MONTE, Mário Ferreira e MONTEIRO, Fernando Conde (coord.). Os novos desafios da cooperação judiciária e policial na União Europeia e da implementação da Procuradoria Europeia. Braga: Centro de Investigação Interdisciplinar em Direitos Humanos/ Escola de Direito da Universidade do Minho, Braga, 2017, pp. 69 e 70.

48 SANTOS, Margarida. Conclusões: A Procuradoria Europeia e a futura arquitetura para a justiça criminal na UE - questões emergentes., in In: SANTOS, Margarida, MONTE, Mário Ferreira e MONTEIRO, Fernando Conde (coord.). Os novos desafios da cooperação judiciária e policial na União Europeia e da implementação da Procuradoria Europeia. Braga: Centro de Investigação Interdisciplinar em Direitos Humanos/Escola de Direito da Universidade do Minho, Braga, 2017, p. 220.

49 Alemanha, Áustria, Bélgica, Bulgária, Chipre, Croácia, Eslováquia, Eslovénia, Espanha, Estónia, Finlândia, França, Grécia, Itália, Letónia, Lituânia, Luxemburgo, Portugal, República Checa e Roménia.

50 A Comissão Europeia confirmou a participação dos Países Baixos, em 1 de agosto de 2018 (JO L 196 de 2 de agosto de 2018) e em 7 de agosto de 2018, a participação de Malta (JO L 201 de 8 de agosto de 2018). 
curso a preparação de todos os procedimentos necessários à sua execução ${ }^{51}$ e as necessárias adaptações aos ordenamentos jurídicos nacionais. Com efeito, não obstante o Regulamento ser aplicável diretamente a todos os Estados-Membros participantes na "cooperação reforçada", o certo é que se afigura necessária a realização de ajustamentos nos respetivos ordenamentos jurídicos, atendendo às implicações (profundas) que inevitavelmente endereça quer ao próprio modus operandi "tradicional" na União Europeia, quer nos ordenamentos jurídicos nacionais ${ }^{52}$.

\subsection{O Regulamento da Procuradoria Europeia - traços gerais ${ }^{53}$ E PERSPETIVAS FUTURAS}

O Regulamento da Procuradoria Europeia “define”, desde logo, o estatuto, a estrutura e a organização da Procuradoria Europeia, a competência

51 Como os relacionados com a nomeação de um diretor administrativo interino, a seleção do procurador-geral europeu (cfr o Aviso de Publicação de uma vaga de procurador-geral europeu - Luxemburgo Agente temporário AD 15 (2018/C 418 A/01)), dos procuradores europeus (em Portugal, por exemplo, ver o Diário da república n. ${ }^{\circ}$ 1/2019, Série II de 2-1-2019 (Aviso n. ${ }^{\circ}$ 5/2019), sobre o processo de candidatura para a seleção de candidatos a designar pelo Estado Português para seleção e nomeação, pelo Conselho da União Europeia, do Procurador Europeu Nacional na Procuradoria Europeia, nos termos do n. ${ }^{\circ} 1$ do artigo $16 .^{\circ}$ do Regulamento (UE) 2017/1939 do Conselho, de 12 de outubro de 2017) e a elaboração do orçamento.

52 Em Portugal, por exemplo, está já em curso a elaboração de uma Proposta de lei para "assegurar a execução do Regulamento da Procuradoria Europeia", onde se estipulam "os termos em que se processa a articulação e a cooperação entre as autoridades nacionais e a Procuradoria Europeia no exercício das funções que esta exerce em território nacional relativamente aos crimes da sua competência, (...) o procedimento interno de designação dos candidatos nacionais a Procurador Europeu, (...) a designação e o estatuto dos Procuradores Europeus Delegados nacionais (...) [e] procede-se à identificação do tribunal de instrução criminal competente para a prática dos atos jurisdicionais relativos ao inquérito quanto aos crimes da competência da Procuradoria Europeia e à identificação da autoridade nacional competente para efeitos de comunicações, informações e consultas, nos termos do Regulamento da Procuradoria Europeia” - cfr. a Exposição de Motivos da Proposta de lei n. ${ }^{\circ}$ 192/ XIII, provada pelo Conselho de Ministros no dia 14 de março de 2019.

53 Seguimos aqui o já descrito em SANTOS, Margarida. A Procuradoria Europeia, a democracia económica e a ação penal dos crimes que lesem os interesses financeiros da União Europeia. In: CARVALHO, Maria Miguel, MESSA, 
da Procuradoria Europeia, as regras processuais aplicáveis às investigações, às medidas de investigação, à ação penal, às garantias processuais.

À luz do Regulamento da Procuradoria Europeia, a Procuradoria Europeia é um órgão da União dotado de personalidade jurídica (artigo $3 .^{\circ}$ ), que goza de garantias de independência (artigo $6 .^{\circ}$ ) e que responde perante o Parlamento Europeu, o Conselho e a Comissão Europeia pelas atividades gerais, aos quais apresenta um relatório anual (artigo 6..$^{\circ}$ n. ${ }^{\circ}$ 2).

No que concerne ao estatuto e estrutura da Procuradoria Europeia (art. os.$^{\circ}$ e ss. do Regulamento da Procuradoria Europeia), a Procuradoria Europeia "é um órgão indivisível da União e funciona como entidade única com estrutura descentralizada" (art. ${ }^{\circ} .^{\circ}$, n. ${ }^{0} 1$ ), sendo organizada a nível central pela Procuradoria Central (constituída pelo Colégio ${ }^{54}$, pelas Câmaras Permanentes ${ }^{55}$,

Ana Flávia, NOHARA, Irene Patrícia (coord.). Democracia Económica e Responsabilidade Social nas Sociedades Tecnológicas. Braga: Escola de Direito da Universidade do Minho, ebook, 2019, pp. 191 e ss.

Cfr. art. ${ }^{\circ} 9$, n. ${ }^{\circ} 1$, de acordo com o qual o Colégio é constituído pelo Procurador-Geral Europeu e por um Procurador Europeu por cada Estado-Membro, sendo responsável pela supervisão geral das atividades da Procuradoria Europeia e pela tomada de decisões sobre questões estratégicas e questões gerais decorrentes de casos individuais, sobretudo para assegurar a coerência, eficiência e coesão da política de ação penal seguida pela Procuradoria Europeia em toda a União (cfr. art. ${ }^{\circ}$ 9. ${ }^{\circ}$, n. ${ }^{\circ} 2$ ). $\mathrm{Na}$ esteira do n. ${ }^{\circ} 3$, do art. ${ }^{\circ}$ 9. $^{\circ}$, o Colégio cria Câmaras Permanentes sob proposta do Procurador-Geral Europeu e de acordo com o regulamento interno da Procuradoria Europeia.

De acordo com o art. $^{\circ} 10 .^{\circ}$, n. $^{\circ} 2$, as Câmaras Permanentes acompanham e orientam as investigações e ações penais conduzidas pelos Procuradores Europeus Delegados; asseguram a coordenação das investigações e das ações penais nos processos transfronteiriços, e a aplicação das decisões tomadas pelo Colégio. As Câmaras Permanentes decidem quanto à deduução da acusação, do arquivamento; da aplicação do procedimento penal simplificado; do reenvio de um processo para as autoridades nacionais; da reabertura da investigação; dão instruções ao Procurador Europeu Delegado para iniciar uma investigação quando não tenha sido aberta nenhuma investigação e dão instruções ao Procurador Delegado Europeu para exercer o direito de avocação; redistribuir processos, depois da análise do projeto de decisão proposto pelo Procurador Europeu Delegado competente. Refira-se, ainda, que face ao art. ${ }^{\circ}$ $10 .^{\circ}$, n. $^{\circ}$ 5, a Câmara Permanente competente, através do Procurador Europeu que supervisiona a investigação ou a ação penal, pode, em conformidade com o direito nacional aplicável, pode dar instruções em casos concretos ao Procurador Europeu Delegado competente. 
pelo Procurador-Geral Europeu ${ }^{56}$, pelos Procuradores-Gerais Europeus Adjuntos $^{57}$, pelos Procuradores Europeus ${ }^{58}$ e pelo Diretor Administrativo ${ }^{59}-\mathrm{n}^{\mathrm{o}}$ 3 , do art. $^{\circ}$ 8. $^{\circ}$ ) e a nível descentralizado (enformado pelos Procuradores Europeus Delegados, localizados nos Estados-Membros ${ }^{60}$ ).

A competência material da Procuradoria Europeia e o seu exercício são definidos nos art. ${ }^{\circ} 22 .{ }^{\circ}$ a $25 .^{\circ}$ do Regulamento da Procuradoria Europeia e na Diretiva (UE) 2017/1371 do Parlamento Europeu e do Conselho, de 5 de julho de 2017, relativa à luta contra a fraude lesiva dos interesses financeiros da União através do direito penal (Diretiva PIF).

56 Na esteira do art. ${ }^{\circ} 11 .^{\circ}$, n. $^{\circ} 1$, o Procurador-Geral Europeu, nomeadamente, dirige a Procuradoria Europeia e organiza os trabalhos da Procuradoria Europeia.

57 Sendo nomeados dois Procuradores-Gerais Europeus Adjuntos para coadjuvar o Procurador-Geral Europeu no desempenho das suas funções e substituí -lo em caso de ausência ou impedimento ( $\operatorname{art}^{\circ} 11 .^{\circ}$, n. $^{\circ} 2$ ).

58 Desde logo, à luz do art. ${ }^{\circ} 12 .^{\circ}$, n..$^{\circ} 1$, os Procuradores Europeus supervisionam as investigações e ações penais pelas quais são responsáveis os Procuradores Europeus Delegados competentes nos respetivos Estados-Membros de origem. Face ao art. ${ }^{\circ} 12 .^{\circ}$, n. $^{\circ}$ 5, "funcionam como ligação e canal de informação entre as Câmaras Permanentes e os Procuradores Europeus Delegados nos respetivos Estados-Membros de origem. Acompanham o cumprimento das funções da Procuradoria Europeia nos respetivos Estados-Membros, em estreita consulta com os Procuradores Europeus Delegados, e asseguram (...) que todas as informações pertinentes sejam fornecidas pela Procuradoria Central aos Procuradores Europeus Delegados e vice-versa”.

59 Sobre as responsabilidades do Diretor Administrativo, que gere a Procuradoria Europeia em termos administrativos e orçamentais e é o seu representante legal para estes efeitos, ver art. ${ }^{\circ} 19 .^{\circ}$ do Regulamento da procuradoria Europeia.

60 De acordo com o art. $^{\circ} 13 .^{\circ}$, n. $^{\circ} 1$, s Procuradores Europeus Delegados agem em nome da Procuradoria Europeia nos respetivos Estados-Membros e têm as mesmas competências que os procuradores nacionais no que respeita a investigar, instaurar a ação penal e deduzir acusação e sustentá-la na instrução e no julgamento, além das competências específicas e do estatuto que o presente regulamento lhes confere, nas condições nele estabelecidas. De acordo com o n. ${ }^{\circ}$ 2, em cada Estado-Membro há dois ou mais Procuradores Europeus Delegados. De referir que os Procuradores Europeus Delegados podem também exercer funções de procuradores nacionais, desde que tal não os impeça de cumprir as obrigações constantes do regulamento (n. ${ }^{\circ} 3$ ), podendo o Procurador Europeu propor à Câmara Permanente que redistribua o processo a outro Procurador Europeu Delegado no mesmo EstadoMembro ou que conduza ele próprio as investigações nos termos do artigo $28 .^{\circ}$, n. ${ }^{\text {os }} 3$ e 4 . 
Na esteira do Regulamento da Procuradoria Europeia (art. ${ }^{\circ} 22$, n. ${ }^{\circ}$ 1), (i) a título principal, a competência da Procuradoria Europeia diz respeito às infrações penais lesivas dos interesses financeiros da União nos termos da Diretiva PIF, tal como transposta para o direito nacional, o que inclui, a fraude lesiva dos interesses financeiros da $\mathrm{UE}^{61}$, o branqueamento de capitais, a corrupção e a apropriação ilegítima (art. ${ }^{\circ} .^{\circ}$ e $4 .^{\circ}$ da Diretiva PIF), sendo igualmente competente, a título secundário, (ii) quanto às infrações relativas à participação numa organização criminosa ${ }^{62}$, se a atividade criminosa dessa organização consistir sobretudo na prática daquelas infrações (n. ${ }^{\circ}$ 3, do mesmo artigo) e (iii) quanto a "qualquer outra infração penal que esteja indissociavelmente ligada" àquelas infrações lesivas dos interesses financeiros, sendo que relativamente àquelas infrações "conexas" a competência só pode ser exercida nos termos do artigo 25..$^{\circ}$ n. ${ }^{\circ} 3$, do Regulamento da Procuradoria Europeia ${ }^{63}$.

${ }^{61}$ Este art. ${ }^{\circ} 22$, n. ${ }^{\circ} 1$, do Regulamento, esclarece, na linha do estipulado no art. ${ }^{\circ}$ $2 .^{\circ},{ }^{\circ}{ }^{\circ}$, da Diretiva PIF, que relativamente a um dos tipos de fraude - às fraudes relativamente aos recursos próprios do IVA - a Procuradoria Europeia só é competente quando os atos ou omissões intencionais em causa (i) estejam relacionados com o território de dois ou mais Estados-Membros e (ii) envolvam prejuízos totais de pelo menos 10 milhões de euros.

62 Tal como definidas na Decisão-Quadro 2008/841/JAI, tal como transposta para o direito nacional.

63 Uma questão fortemente debatida relaciona-se com a própria opção da base legal da competência material da Procuradoria Europeia, que em abstrato, poderia assentar nos art. $.^{\text {s }} 83 .^{\circ}, 86 .^{\circ}$ ou $325 .^{\circ}$, todos do TFUE. Depois das difíceis negociações, acabou por vingar a base legal do art. ${ }^{\circ} 83 .^{\circ}$, n. $^{\circ} 2$, do TFUE. Cremos, contudo, tal como alguma doutrina perfilha, que seria preferível que a base legal fosse a do art. ${ }^{\circ} 86 .^{\circ}$ do TFUE (ou eventualmente a do $325 .^{\circ}$ do TFUE), onde o regulamento da Procuradoria Europeia igualmente definisse as infrações sob a alçada da Procuradoria Europeia. Sobre este assunto já nos dedicamos noutra sede. Ver o nosso, O quadro legislativo (substantivo) da Procuradoria Europeia - Algumas reflexões. In: MOTA, Helena et. al. (coord.). XX Estudos Comemorativos dos 20 anos da FDUP, Vol. II. Coimbra: Almedina, 2017 e o nosso, The definition of the competence ratione materiae of the European Public Prosecutor's Office and the substantive legality principle - the way forward. Portuguese Law Review, n. ${ }^{\circ}$ 0, Vol. 1, Spring 2016. Ver ainda, entre outros, LigetI, katalin. Approximation of substantive criminal and the establishment of the European Public Prosecutor's Office. In: GALLI, Francesca, WEYEMBERG, Anne (Ed.). Approximation of substantive criminal law in the EU - The way forward. Belgium: Editions de l'Université de Bruxelles, 2013, especialmente pp. 75 e ss. e VERVAELE, John A. E. The material 
Olhando para as opções gizadas no texto do Regulamento da Procuradoria Europeia e na Diretiva PIF ${ }^{64}$, como já noutro escrito acentuámos, somos de entendimento "que o modelo gizado (...) afigura-se um modelo espartilhado, podendo germinar assimetrias no exercício da ação penal por parte da Procuradoria Europeia, desde logo em função legislação penal aplicável. De forma perfunctória, podemos referir desde já que o nível de harmonização pretendido na Diretiva PIF, especialmente no que diz respeito às sanções máximas aplicáveis (inexistem as sanções mínimas como previsto na versão inicial da Proposta PIF $^{65}$ ), à autoria e cumplicidade, à responsabilidade das pessoas coletivas e aos prazos de prescrição (finalmente inseridos), afigura-se «modesto»" ${ }^{66}$.

Na verdade, no que diz respeito ao objeto material de atuação da Procuradoria Europeia, duas questões emergem desde logo. Por um lado, uma vez que o exercício transnacional da ação penal assenta (sobretudo)

scope of competence of the European Public Prosecutor's office: a harmonised national patchwork?. Centro Studi di Diritto Penale Europeo, 2015; SICURELLA, Rosaria, Setting up a European Criminal policy for the Protection of EU Financial interests: guidelines for a coherent definition of the Material Scope of the European Public Prosecutor's Office. In: Ligeti, Katalin, (ed). Toward a Prosecutor for the European Union. Volume 1: A Comparative Analysis. Oxford: Hart Publishing, 2013, pp. 885 e ss. Ver também o que se disse supra na nota de rodapé 33.

64 Para uma análise das disposições da Diretiva PIF, dando conta de algumas das inovações relativamente à Convenção relativa à proteção dos interesses financeiros das Comunidades Europeias de 26 de julho de 1995 (Convenção PIF) e seus Protocolos, ver SANTOS, Margarida. A Procuradoria Europeia, a democracia económica e a ação penal dos crimes que lesem os interesses financeiros da União Europeia. In: CARVALHO, Maria Miguel, MESSA, Ana Flávia, NOHARA, Irene Patrícia (coord.). Democracia Económica e Responsabilidade Social nas Sociedades Tecnológicas. Braga: Escola de Direito da Universidade do Minho, ebook, 2019, pp. 196 e ss.

$65{\text { Ver } \text { art. }^{\circ} \text { 8. }}^{\circ}$ ("Penas de prisão mínimas") e art. 9 ("Tipos de sanções mínimas aplicáveis às pessoas coletivas"), da Proposta de Diretiva sobre a proteção dos interesses financeiros - COM(2012) 363 final.

66 Cfr. SANTOS, Margarida. A Procuradoria Europeia, a democracia económica e a ação penal dos crimes que lesem os interesses financeiros da União Europeia. In: CARVALHO, Maria Miguel, MESSA, Ana Flávia, NOHARA, Irene Patrícia (coord.). Democracia Económica e Responsabilidade Social nas Sociedades Tecnológicas. Braga: Escola de Direito da Universidade do Minho, ebook, 2019, p. 195. 
na transposição nacional da Diretiva PIF “as (eventuais) divergências no contexto da transposição da Diretiva PIF poderão assumir contornos relevantes", pelo que se revela fundamental "a realização de um exame minucioso das implementações nacionais da Diretiva PIF, com consequências em caso de falhas ou inconsistências na legislação nacional" ${ }^{67}$. Por outro lado, de acordo com o art. ${ }^{0} 25 .{ }^{\circ}$, n. ${ }^{\circ} 3$, al. a), do Regulamento da Procuradoria Europeia, o exercício das competências sobre as infrações indissociavelmente ligadas às "infrações principais", determinado com base na gravidade das sanções previstas no direito nacional, poderá originar discrepâncias nesta regra de conexão ${ }^{68}$.

Com efeito, o Regulamento estabelece um regime (altamente) complexo de exercício de competência da Procuradoria Europeia, contemplando igualmente situações em que este órgão não poderá intervir, muito embora estejam em causa os crimes que lesem os interesses financeiros da União Europeia, na medida em que os n. ${ }^{\text {os }} 2$ e 3 do art. ${ }^{\circ}$ 25. ${ }^{\circ}$, do Regulamento da Procuradoria Europeia estabelecem limitações ao exercício da Procuradoria Europeia ${ }^{69}$.

67 Cf. idem, p. 195. Ver MARLETTA, Angelo. The material competence of the European Public Prosecutor's Office (EPPO) and the PIF Directive. In: SANTOS, Margarida, MONTE, Mário Ferreira e MONTEIRO, Fernando Conde (coord.). Os novos desafios da cooperação judiciária e policial na União Europeia e da implementação da Procuradoria Europeia. Braga: Centro de Investigação Interdisciplinar em Direitos Humanos/Escola de Direito da Universidade do Minho, Braga, 2017, p. 94, nota 34.

Cf. SANTOS, Margarida. A Procuradoria Europeia, a democracia económica e a ação penal dos crimes que lesem os interesses financeiros da União Europeia. In: CARVALHO, Maria Miguel, MESSA, Ana Flávia, NOHARA, Irene Patrícia (coord.). Democracia Económica e Responsabilidade Social nas Sociedades Tecnológicas. Braga: Escola de Direito da Universidade do Minho, ebook, 2019, pp. 195/196.

Nos termos do n. ${ }^{\circ}$ 2, se uma infração penal que cabe na alçada da Procuradoria Europeia tiver lesado ou for suscetível de lesar os interesses financeiros da União em menos de 10 mil euros, a Procuradoria Europeia só pode exercer a sua competência em duas situações: (i) se "[o] processo tiver repercussões a nível da União que exijam que a Procuradoria proceda a uma investigação" al. a); ou (ii) se "[o]s funcionários ou outros agentes da União Europeia, ou membros das instituições da União, puderem ser suspeitos de ter cometido a infração" - al. b). Além disso, nos termos do n. ${ }^{\circ}$ 3, a Procuradoria Europeia não irá exercer a sua competência relativamente às infrações penais que cabem na sua competência e reenviará o caso às entidades nacionais competentes nos 
As regras processuais aplicáveis às investigações, medidas de investigação e o exercício da ação penal estão descritas nos art. ${ }^{\circ} 26 .^{\circ}$ e seguintes do Regulamento da procuradoria Europeia.

Desde logo, por regra, de acordo com o $\operatorname{art}^{\circ}{ }^{\circ} 26 .^{\circ}$, n. $^{\circ} 3$ do Regulamento da Procuradoria Europeia, o processo é aberto e instruído por um Procurador Europeu Delegado do Estado-Membro onde está centrada a atividade criminosa, ou no Estado-Membro onde tiverem sido cometidas a maior parte das infrações (no caso de infrações conexas).

No que diz respeito às medidas de investigação da Procuradoria Europeia, verifica-se, nos art. ${ }^{\text {os }} 30$ e seguintes do Regulamento da Procuradoria Europeia, um "regime misto" para as medidas de investigação e no que respeita às condições em que podem ser ordenadas pelos Procuradores Europeus Delegados, que entrelaça as legislações nacionais com a legislação da UE. Com efeito, o art. ${ }^{\circ} 30 .^{\circ}$ do Regulamento da Procuradoria Europeia prevê um conjunto mínimo de medidas de investigação ao dispor dos Procuradores Europeus Delegados (que podem, em determinadas situações, ser sujeitas a determinadas condições/limitações, de acordo com o disposto no direito nacional aplicável, a que acresce a possibilidade de os Procuradores Europeus Delegados pedirem ou ordenarem outras medidas que estejam ao dispor dos procuradores, de acordo com o direito nacional. Nos processos transfronteiriços, o Procurador Europeu Delegado competente deverá poder contar com os Procuradores Europeus Delegados assistentes quando for necessário tomar medidas noutros Estados-Membros ${ }^{70}$.

termos do art. ${ }^{\circ} 34 .^{\circ}$, em duas distintas situações. Por um lado, i) nas situações em que a sanção máxima prevista no direito nacional para uma infração abrangida pela competência a título principal $\left(22 .^{\circ},{ }^{\circ}{ }^{\circ} 1\right)$ da Procuradoria Europeia for de severidade igual ou inferior à da sanção máxima para uma infração indissociavelmente ligada ( art. $^{\circ} 22^{\circ},{ }^{\circ} .^{\circ} 3$ ), a não ser que esta última infração tenha sido instrumental para cometer aquela infração - al. a); por outro, ii) nas situações em que se presuma que o prejuízo causado ou suscetível de ser causado aos interesses financeiros da União Europeia pela prática de qualquer infração da competência da Procuradoria Europeia (com exceção da fraude relativa às despesas não relacionadas com a contratação pública; da fraude relativa às despesas relacionadas com a contratação pública e da fraude em relação a receitas provenientes dos recursos próprios do IVA) não ultrapassa o prejuízo causado ou suscetível de ser causado a outra vítima - al. b)

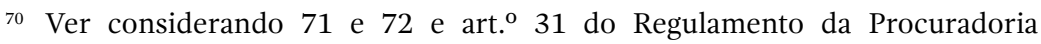
Europeia. 
A Procuradoria Europeia, à luz do Regulamento da Procuradoria Europeia, exerce a ação penal de acordo com o princípio da legalidade. A decisão de deduzir acusação deve em princípio ser tomada pela Câmara Permanente competente, com base num projeto de decisão emanado do Procurador Europeu Delegado ${ }^{71}$. Há também a possibilidade, caso ela exista no sistema jurídico nacional, de aplicação de procedimentos penais simplificados, nas condições estabelecidas pelo direito nacional e nas situações previstas pelo regulamento ${ }^{72}$.

Relativamente ao controlo jurisdicional, os atos processuais da Procuradoria Europeia que se destinem a produzir efeitos jurídicos em relação a "terceiros", bem como a sua não adoção quando a Procuradoria Europeia estivesse juridicamente obrigada de acordo com o disposto no Regulamento, são objeto de fiscalização jurisdicional por parte dos Tribunais nacionais, de acordo com os requisitos e formalidades previstos no direito nacional ${ }^{73}$.

Numa palavra, do exposto resulta que os desafios e complexidades que a intervenção penal (nacional e da União Europeia) enfrenta no momento presente são inúmeras, e caem em diferentes domínios (institucionais, processuais e substantivos), cobrindo temáticas como as relacionadas com a estrutura da Procuradoria Europeia e sua interseção com os sistemas nacionais, as do exercício da ação penal, do controlo judiciário e da intervenção do Tribunal de Justiça da União Europeia e as da própria definição do âmbito material de atuação da Procuradoria Europeia.

71 Cfr. considerando 78 e art. ${ }^{\circ} 35 .^{\circ}$ e seguintes do Regulamento da Procuradoria Europeia.

72 Ver considerando 82 e art. $^{\circ} 40 .^{\circ}$ do Regulamento da Procuradoria Europeia.

73 Ver considerando 87 e art. ${ }^{\circ} 42 .^{\circ}$ do Regulamento da Procuradoria Europeia. Contempla-se, ainda, a intervenção do Tribunal de Justiça da União Europeia em determinadas matérias descritas no art. ${ }^{\circ} 42 .^{\circ}$, n. ${ }^{\circ} 2$ a 8 , aqui se englobando, por exemplo, a decisão a título prejudicial, nomeadamente a propósito da interpretação dos art. ${ }^{o s} 22 .^{\circ}$ e $25 .^{\circ}$ do Regulamento da Procuradoria Europeia quanto a qualquer conflito de competências entre a Procuradoria Europeia e as autoridades nacionais competentes (art. ${ }^{\circ} 42 .^{\circ},{ }^{\circ}{ }^{\circ} 2$, do Regulamento da Procuradoria Europeia), quer, por exemplo, a fiscalização relativamente às decisões de arquivamento da Procuradoria Europeia, na medida em que sejam diretamente impugnadas com base no Direito da União, nos termos do art. $^{\circ} 263 .^{\circ}, 4 .^{\circ}$ parágrafo do TFUE. 
Além disso, numa altura em que "a execução" deste Regulamento está em curso, volta a vir ao de cima uma questão que nunca deixou de estar no centro do debate (sobretudo académico), por diferentes motivos: a relacionada com o âmbito material de atuação da Procuradoria Europeia.

A opção tomada pela Comissão Europeia em 17 de julho de 2013 e que se manteve no texto do Regulamento da Procuradoria Europeia em cingir-se, pelo menos num primeiro momento, à proteção dos interesses financeiros transparece, de facto, a solução possível, como já relatámos.

O certo é que recentemente a Comissão Europeia relança, em termos políticos, o debate, emitindo uma Comunicação ao Parlamento Europeu e ao Conselho Europeu destinada a alargar as competências da Procuradoria Europeia "aos crimes terroristas transnacionais"74. Pretende-se, pois, primeiramente, que o Conselho Europeu altere o disposto no artigo 86. ${ }^{\circ}$, n. ${ }^{\text {os }} 1$ e 2, do Tratado sobre o Funcionamento da União Europeia de modo a alargar a competência material da Procuradoria Europeia a todos, alguns ou apenas um dos "crimes graves com dimensão transfronteiriça”. Aí se refere que, "é necessária uma dimensão europeia mais forte para garantir um acompanhamento judicial uniforme, eficaz e eficiente destes crimes em todo o espaço europeu de liberdade, de segurança e de justiça. Os crimes terroristas afetam todos os EstadosMembros e a União no seu conjunto, razão pela qual deve ser considerada uma solução a nível europeu. Neste contexto, parece demonstrado que a Procuradoria Europeia pode acrescentar valor à luta contra crimes terroristas e à resolução das lacunas identificadas"75. O debate carece, também por isso, de ser intensificado neste ponto.

Com efeito, em abstrato, podem ser objeto desta tutela supranacional tanto os bens jurídicos titulados pelos cidadãos da comunidade (a fim de se exercer a ação penal relativamente à criminalidade de natureza ou tendência transfronteiriça ou cuja repressão só assuma eficácia de modo coordenado - o domínio do art. ${ }^{\circ} 83 .^{\circ}$ ) como os bens jurídicos

74 Cfr. Comunicação da Comissão ao Parlamento Europeu e ao Conselho Europeu - Uma Europa que protege: uma iniciativa destinada a alargar as competências da Procuradoria Europeia aos crimes terroristas transnacionais $\operatorname{COM}(2018) 641$ final.

75 Cfr. Idem,p. 9. 
titulados pelas instituições europeias - cabendo aqui, por exemplo, os crimes contra os interesses económicos e financeiros da $\mathrm{UE}^{76}$.

Não obstante, cremos que, ao contrário do que sucede com os interesses financeiros da União Europeia, no que concerne aos "interesses comuns" - e não "próprios” da União - que poderiam ser, grosso modo, caracterizados pela expressão "criminalidade grave com dimensão transfronteiriça”, "urge aprofundar o estudo da sua natureza, afigurandose verdadeiramente "precipitado» postular a existência de "novos bens jurídicos tout court". Como já adiantámos, "importa «ponderar» sobre a existência (igualmente) de um interesse na prevenção e repressão do crime que vá para além da «soma dos interesses dos Estados-Membros», associado à cidadania europeia", refletindo, porventura, "sobre os interesses da União de uma forma mais ampla que inclua a ideia de uma "potencial vitimização da UE»", enquanto reflexo da existência de um interesse dos cidadãos da União Europeia a uma proteção adequada ${ }^{77}$.

Podemos já acrescentar que perspetivamos a Procuradoria Europeia como um plus na construção de um efetivo espaço de liberdade, segurança e justiça. Com efeito, “[e]stabelecer um novo modelo de intervenção penal da Procuradoria Europeia apenas para combater a criminalidade advinda, sobretudo, do próprio funcionamento da União poderá ser alvo de críticas. Na verdade, a promoção de um espaço de liberdade, segurança e justiça vai muito para além, numa «visão holística», do que estabelecer um modelo de uma «Procuradoria Financeira» assente apenas na proteção dos «interesses financeiros da União»"78.

Se compreendemos a necessidade de se avançar para uma "Europa que protege [os cidadãos]", onde a Procuradoria Europeia pode efetivamente "colmatar as lacunas existentes" 79 , cremos que se afigura este "avanço" prematuro, podendo, sobremaneira, beliscar os princípios estruturantes da

76 Cfr. o nosso, Para um (novo) modelo de intervenção penal na União Europeia: uma reflexão a partir do princípio da legalidade como limite material de atuação da Procuradoria Europeia. Lisboa: Rei dos Livros, 2016, p.212. Par maiores desenvolvimentos ver pp. 211 e ss.

77 Cfr. idem, p.212. Par maiores desenvolvimentos ver pp. 215.

78 Idem, p. 329.

79 Cfr. Comunicação da Comissão ao Parlamento Europeu e ao Conselho Europeu - Uma Europa que protege: uma iniciativa destinada a alargar as 
intervenção penal, como o princípio da legalidade ${ }^{80}$. Neste sentido, somos de entendimento que " $[\mathrm{n}] \mathrm{o}$ que diz respeito àqueles - outros - interesses, que poderemos, grosso modo, abarcar como incluídos na definição constante no n. ${ }^{\circ} 4$ do art. $^{\circ} 86 .^{\circ}$ do TFUE ("criminalidade grave com dimensão transfronteiriça), designados por muitos como os interesses da União «hard-core», atendendo à ainda insuficiente reflexão acerca da natureza dos interesses em causa, por um lado, e apenas à possível harmonização através de diretivas, por outro, parecem inexistir condições para que se avance para este âmbito material de atuação da Procuradoria Europeia”. Desde logo, cremos que "o nível de harmonização alcançado até agora neste âmbito torna inviável, segundo cremos, uma coerente, igual, certa e precisa atuação da Procuradoria Europeia no exercício da ação penal"

Numa palavra, a eficácia pretendida - e que parece ser o cerne da Cominação da Comissão Europeia no sentido do alargamento das competências materiais da Procuradoria Europeia - tem de estar ligada à essencialidade da intervenção penal, também no contexto do exercício da ação penal ${ }^{82}$.

competências da Procuradoria Europeia aos crimes terroristas transnacionais - $\operatorname{COM(2018)~} 641$ final, p. 8.

80 Ver o nosso, Para um (novo) modelo de intervenção penal na União Europeia: uma reflexão a partir do princípio da legalidade como limite material de atuação da Procuradoria Europeia. Lisboa: Rei dos Livros, 2016, entre outras, p. 328. Como aí encarámos, “[u]m modelo de intervenção penal limitado aos interesses financeiros parece-nos ser a possibilidade adequada e viável no momento presente. Com efeito, em prol da defesa do princípio da legalidade da intervenção penal, a concretização de uma Procuradoria Europeia terá de estar associada à definição do âmbito material de atuação através do método da unificação, onde através de regulamento se definam, de forma uniforme e equivalente, os tipos legais de crime, no "espaço único da União".

81 Ver o nosso, Para um (novo) modelo de intervenção penal na União Europeia: uma reflexão a partir do princípio da legalidade como limite material de atuação da Procuradoria Europeia. Lisboa: Rei dos Livros, 2016, p. 329.

82 Como refere Anabela Miranda Rodrigues, a propósito da intervenção de caráter substantivo, mas que cremos, que deve aqui ser ponderada na medida em que com esta relacionada, "[é] esta condição [a essencialidade] que funciona como fundamento e limite - material - da intervenção penal em causa levada a efeito a nível da União" - para maiores desenvolvimentos ver Rodrigues, Anabela Miranda, Direito Penal Económico: uma política criminal na era compliance, Coimbra, Almedina, 2019, p. 88. Em súmula, “[é], pois, importante ter em conta que é uma consideração do caráter necessário (indispensável) da 
O Regulamento da Procuradoria Europeia enceta "um novo modelo de intervenção penal na União Europeia”, um “tertium genus de intervenção penal na UE" ${ }^{83}$, na medida em que, não obstante não estar em causa uma integração penal pura, o certo é que se deu mais um passo em frente neste sentido, saindo igualmente reforçada a cooperação e a harmonização.

\section{Considerações Finais}

O Direito Penal da União Europeia (que inclui a dimensão substantiva, processual e institucional) é uma das áreas da União Europeia que mais tem evoluído, verificando-se novas linhas de intervenção penal, nomeadamente relacionadas com um novo olhar direcionado à proteção dos direitos dos participantes processuais envolvidos. Numa palavra, é a existência de um verdadeiro sistema de justiça criminal da União Europeia que vai ganhando espaço, estando "ao serviço do arguido, da vítima e do condenado".

O Direito Penal da União Europeia tem visto, pois, alargado o seu âmbito de intervenção, nas várias dimensões que compõe a intervenção penal da União Europeia, sobremaneira a partir do Tratado de Lisboa.

Sobretudo na ótica institucional, parece assistir-se a uma "viragem” de um modelo de cooperação para um modelo com laivos mais acentuados de integração, embora com especificidades.

Em certa medida, e em muito menor grau do que na versão inicial da Proposta da Comissão Europeia, há, em certos momentos vertidos no Regulamento da Procuradoria Europeia, uma certa lógica "federalista", "supranacional", mas mitigada com o modelo de "cooperação".

intervenção penal baseada em prova relevante a partir de investigação criminológica e de dados empíricos e literatura científica que pode fazer com que aquela condição funcione realmente como limitadora da utilização do direito penal e se assuma como um critério legitimador materialmente definido" (pp. 92/93). Ver também RODRIGUES, Anabela Miranda, "Direito penal europeu pós-Lisboa - um direito penal funcionalista?”, Revista de Legislação e Jurisprudência, Ano 163, n. ${ }^{\circ}$ 4004, maio-junho, 2017.

83 Cf. o nosso Para um (novo) modelo de intervenção penal na União Europeia: uma reflexão a partir do princípio da legalidade como limite material de atuação da Procuradoria Europeia, Lisboa, Rei dos Livros, 2016, entre outras na p. 343. 
Constitui por isso uma intervenção penal Europeia apesar de inovadora, revolucionária, mas "contida". A eficácia pretendida - e que parece ser o cerne da Comunicação da Comissão Europeia no sentido do alargamento das competências materiais da Procuradoria Europeia - tem de estar ligada à essencialidade da intervenção penal, também no contexto do exercício da ação penal e, nessa medida, importa compreender que interesses se pretende proteger através de uma tutela assente num exercício transnacional da ação penal. Nesta medida, se compreendemos a necessidade de se avançar para uma Europa que protege os cidadãos da criminalidade grave com dimensão transfronteiriça, cremos que ainda se afigura prematuro o alargamento do objeto material de atuação da Procuradoria Europeia para além dos crimes que lesem os interesses financeiros da União Europeia.

Cremos, no entanto, que se "vai caminhando" na direção certa para um sistema de justiça, mas com ainda muitas incertezas e dúvidas, que poderão beliscar princípios estruturantes de um Estado de Direito.

Importa, pois, intensificar a reflexão, sempre na perspetiva de se alcançar o equilíbrio entre os interesses conflituantes (os da prossecução penal e os da proteção dos direitos fundamentais).

\section{REFERÊNCIAS}

ASP, Petter et. al. Manifiesto sobre la política criminal europea, 2009. Disponível em <http://www.crimpol.eu./wp-content/Spanisch_Manifest_gesetzt-korr.pdf >. Acesso em: 28 mar. 2019.

BECK, Ulrich, Risikogesellschaft. Auf dem Weg in eine andere Moderne. Frankfurt a.M.: Suhrkamp, 1986.

CSONKA, Peter. General presentation of the proposal and main issues: the state of negotiations, solutions reached and main issues to be resolved, In: SANTOS, Margarida, MONTE, Mário Ferreira e MONTEIRO, Fernando Conde (coord.). Os novos desafios da cooperação judiciária e policial na União Europeia e da implementação da Procuradoria Europeia. Braga: Centro de Investigação Interdisciplinar em Direitos Humanos/Escola de Direito da Universidade do Minho, Braga, 2017. Disponível em <http://www.jusgov.uminho.pt/publicacoes/os_novos_desafios_cooperacao_jud_e_policial_ue_implementacao_da_pe/>. Acesso em: 28 mar. 2019. 
DELMAS-MARTY, Mireille. Les contradictions du droit pénal. Revue de science criminelle et de droit pénal comparé, n. ${ }^{\circ}$ 1, 2000.

Mitsilegas, Valsamis. EU Criminal Law. Oxford: Hart Publishing, 2009.

CAEIRO, Pedro (ed.). European Criminal Law in the Global Context: Values, Principles and Policies, Special issue of the New Journal of European Criminal Law, março 2019. https://doi.org/10.1177/2032284419836519

CAEIRO, Pedro, FIDALGO, Sónia e RODRIGUES, João Prata.The evolving notion of mutual recognition in the CJEU's case law on detention. Maastricht Journal of European and Comparative Law, Vol. 25, n. ${ }^{\circ}$ 6, 2019. https://doi. org/10.1177/1023263X18822787

CAEIRO, Pedro (org.). Proceedings of the conference European criminal law in the global context: values, principles and policies. Coimbra: Coimbra: Instituto Jurídico/ Faculdade de Direito da Universidade de Coimbra, 2017. Disponível em https:// www.ij.fd.uc.pt/publicacoes/coloquios/ECLAN_2017.pdf

CAEIRO, Pedro. Reaction to "European Criminal Justice in the global context: challenges and perspectives”. In: CAEIRO, Pedro (org.). Proceedings of the conference European criminal law in the global context: values, principles and policies. Coimbra: Instituto Jurídico/ Faculdade de Direito da Universidade de Coimbra, 2017. Disponível em < https://www.ij.fd.uc.pt/publicacoes/coloquios/ECLAN_2017. pdf>. Acesso em: 28 mar. 2019.

CAEIRO, Pedro. Reconhecimento mútuo, harmonização e confiança mútua (primeiro esboço de uma revisão). In: SANTOS, Margarida, MONTE, Mário Ferreira e MONTEIRO, Fernando Conde (coord.). Os novos desafios da cooperação judiciária e policial na União Europeia e da implementação da Procuradoria Europeia. Braga: Centro de Investigação Interdisciplinar em Direitos Humanos/Escola de Direito da Universidade do Minho, 2017. Disponível em < http://www.jusgov.uminho. pt/publicacoes/os_novos_desafios_cooperacao_jud_e_policial_ue_implementacao_da_pe/>. Acesso em: 28 mar. 2019.

CAEIRO, Pedro. Introdução (ou de como todo o processo penal começa com uma constituição de direitos). In: CAEIRO, Pedro (org.). A Agenda da União Europeia sobre os Direitos e Garantias da Defesa em Processo Penal: a "segunda vaga" e o seu previsivel impacto sobre o direito português. Coimbra: Instituto Jurídico/Faculdade de Direito da Universidade de Coimbra, 2015. Disponível em <https://www. uc.pt/fduc/ij/areasinvestigacao/pdfs/ebook_1_comentarios.pdf >. Acesso em: 28 mar. 2019. 
CAEIRO, Pedro. The influence of the EU on the 'blurring' between administrative and criminal law”. In: GALLI, Francesca, WEYEMBERGH, Anne. Do Labels still Matter? Blurring Boundaries between Administrative and Criminal Law. The Influence of the EU. Bruxelles: Ed. Univ. Bruxelles, 2014.

Caeiro, Pedro. Fundamento, conteúdo e limites da jurisdição penal do Estado - o caso português. Coimbra: Coimbra Editora, 2010.

DELMAS-MARTY, Mireille, VERVAELE, J. A. E. A aplicação do Corpus Juris nos Estados-Membros. Utrecht: Intersentia, 4 Vol., 2000.

DELMAS-MARTY, Mireille (DIR.), Corpus Juris relativo às disposições penais para a proteç̧ão dos interesses financeiros da União Europeia. Paris: Economica, 1997.

DIAS, Jorge de Figueiredo. O direito penal entre a 'sociedade industrial' e a “sociedade do risco. In: Estudos em Homenagem ao Prof. Doutor Rogério Soares. Coimbra: Coimbra Editora, 2001.

GEELHOED, Willem, ERKELENS, Leendert Hendrik, MEIJ, Arjen (Eds.). Shifting Perspectives on the European Public Prosecutor's Office, T.M.C. The Hague: Asser Press, 2018.

LIGETI, Katalin. Approximation of substantive criminal and the establishment of the European Public Prosecutor's Office. In GALLI, Francesca, WEYEMBERG, Anne (Ed.). Approximation of substantive criminal law in the EU - The way forward. Belgium: Editions de 1'Université de Bruxelles, 2013.

MARLETTA, Angelo. The material competence of the European Public Prosecutor's Office (EPPO) and the PIF Directive. In: SANTOS, Margarida, MONTE, Mário Ferreira e MONTEIRO, Fernando Conde (coord.). Os novos desafios da cooperação judiciária e policial na União Europeia e da implementação da Procuradoria Europeia. Braga: Centro de Investigação Interdisciplinar em Direitos Humanos/ Escola de Direito da Universidade do Minho, Braga, 2017. Disponível em <http:// www.jusgov.uminho.pt/publicacoes/os_novos_desafios_cooperacao_jud_e_policial_ue_implementacao_da_pe/>. Acesso em: 28 mar. 2019.

MENDES, Paulo de Sousa. Comentário ao art. ${ }^{\circ} 325^{\circ}$. $^{\circ}$ In: PORTO, Manuel Lopes, ANASTÁCIO, Gonçalo (coord.), Tratado de Lisboa Anotado e Comentado. Coimbra: Almedina, 2012.

MITSILEGAS, VALSAMIs, BERGSTRÖM, Maria, KONSTADINIDES, Theodore (ed.). Research handbook on EU Criminal Law, Cheltenham, UK, Northampton, MA, USA: Edward Elgar, 2016. https://doi.org/10.4337/9781783473311. 
MONTE, Mário Ferreira. O Direito Penal Europeu de "Roma" a "Lisboa" - Subsídios Para a Sua Legitimação. Lisboa: Quid Juris Sociedade Editora, 2009.

MONTE, Mário Ferreira. O sistema judicial europeu e o controlo jurisdicional em matéria penal: reflexões em torno do direito vigente e do Tratado de Lisboa. In: ANDRADE, Manuel da Costa, ANTUNES, Maria João, SOUSA, Susana Aires de (org.). Estudos em Homenagem ao Prof. Doutor Jorge de Figueiredo Dias, Vol. I. Coimbra: Coimbra Editora, 2009.

MORALES ROMERO, Marta Muñoz de. El legislador penal Europeo: legitimidad y racionalidad. Madrid: Editorial Civitas, S.A., 2011.

RODRIGUES, Anabela Miranda. Direito Penal Económico: uma política criminal na era compliance. Coimbra: Almedina, 2019.

RODRIGUES, Anabela Miranda. O Direito Penal europeu à luz do princípio da necessidade - o caso do abuso do mercado. Católica Law Review, Volume I, n. ${ }^{\circ}$, nov. 2017.

RODRIGUES, Anabela Miranda, Direito penal europeu pós-Lisboa - um direito penal funcionalista?.In: SANTOS, Margarida, MONTE, Mário Ferreira e MONTEIRO, Fernando Conde (coord.). Os novos desafios da cooperação judiciária e policial na União Europeia e da implementação da Procuradoria Europeia. Braga: Centro de Investigação Interdisciplinar em Direitos Humanos/Escola de Direito da Universidade do Minho, 2017. Disponível em <http://www.jusgov.uminho. pt/publicacoes/os_novos_desafios_cooperacao_jud_e_policial_ue_implementacao_da_pe/>. Acesso em: 28 mar. 2019 (artigo igualmente publicado na Revista de Legislação e Jurisprudência, Ano $146^{\circ}$, no 4004, Julho-Agosto, 2017).

RODRIGUES, Anabela Miranda. Direito penal económico - é legítimo? é necessário? Revista Portuguesa de Ciência Criminal, Ano 26, 2016.

RODRIGUES, Anabela Miranda. O Direito penal Europeu emergente. Coimbra: Coimbra Editora, 2008.

RODRIGUES, Anabela Miranda e MOTA, José Luís Lopes da. Para uma Política Criminal Europeia. Quadro e instrumentos jurídicos da cooperação judiciária em matéria penal no espaço da União Europeia. Coimbra: Coimbra Editora, 2002.

SANTOS, Margarida. A Procuradoria Europeia, a democracia económica e a ação penal dos crimes que lesem os interesses financeiros da União Europeia. In: CARVALHO, Maria Miguel, MESSA, Ana Flávia, NOHARA, Irene Patrícia (coord.). 
Democracia Económica e Responsabilidade Social nas Sociedades Tecnológicas. Braga: Escola de Direito da Universidade do Minho, ebook, 2019. Disponível em <http:// bit.ly/demo-economica-dnl>. Acesso em: 28 mar. 2019.

SANTOS, Margarida. O quadro legislativo (substantivo) da Procuradoria Europeia Algumas reflexões. In: MOTA, Helena et. al. (coord.). XX Estudos Comemorativos dos 20 anos da FDUP, Vol. II. Coimbra: Almedina, 2017.

SANTOS, Margarida. The definition of the competence ratione materiae of the European Public Prosecutor's Office and the substantive legality principle - the way forward. Portuguese Law Review, n. ${ }^{\circ}$ 0, Vol. 1, Spring 2016. Disponível em <http://portugueselawreview.pt/current-issue.html>. Acesso em: 28 mar. 2019.

SANTOS, Margarida, Para um (novo) modelo de intervenção penal na União Europeia: uma reflexão a partir do princípio da legalidade como limite material de atuação da Procuradoria Europeia. Lisboa: Rei dos Livros, 2016.

SANTOS, Marina Oliveira Teixeira dos. A expansão do Direito Penal europeu frente à subsidiariedade da tutela penal: alternatividade a partir da Mediação Penal de Adultos portuguesa, Revista Brasileira de Direito Processual Penal, Porto Alegre, vol. 5, n.1, jan-abr.2019. https://doi.org/10.22197/rbdpp.v5i1.189.

SATZGER, Helmut. Is mutual recognition a viable general path for cooperation? (commented structure and conclusion-draft). In CAEIRO, Pedro (org.). Proceedings of the conference European criminal law in the global context: values, principles and policies. Coimbra: Instituto Jurídico/ Faculdade de Direito da Universidade de Coimbra, 2017. Disponível em < https://www.ij.fd.uc.pt/publicacoes/coloquios/ ECLAN_2017.pdf>. Acesso em: 28 mar. 2019.

SICURELLA, Rosaria, Setting up a European Criminal policy for the Protection of EU Financial interests: guidelines for a coherent definition of the Material Scope of the European Public Prosecutor's Office. In: LIGETI, katalin, (ED). Toward a Prosecutor for the European Union. Volume 1: A Comparative Analysis. Oxford: Hart Publishing, 2013.

SILVA SÁNCHEZ, Jesús-María. La expansión del Derecho Penal, Aspectos de la política criminal en las sociedades postindustriales, $2 .^{\mathrm{a}}$ ed., revista e aumentada. Madrid: Civitas, 2001.

WADE, Marianne. A European public prosecutor: potential and pitfalls. Crime Law Soc Change, mar., 2013. Disponível em <http://download.springer.com/static/pdf/940/art\%253A10.1007\%252Fs10611-012-9406-x. 
pdf?auth66=1382393008_5cf47e301d19135857c7d662fc76fc0d\&ext=.pdf >. Acesso em: 28 mar. 2019.

WADE, Marianne (coord.). EuroNEEDs, Evaluating the need for and the needs of a European Criminal Justice System. Max-Planck-Institute für ausländisces und internationales Strafrecht, Preliminary report, 2011. Disponível em <http://www.mpicc. de/shared/data/pdf/euroneeds_report_jan_2011.pdf>. Acesso em: 28 mar. 2019.

WEYEMBERGH, Anne. Reaction to "Transforming the ne bis in idem principle into a fundamental right in the EU”. In CAEIRO, Pedro (org.). Proceedings of the conference European criminal law in the global context: values, principles and policies. Coimbra: Instituto Jurídico/ Faculdade de Direito da Universidade de Coimbra, 2017. Disponível em < https://www.ij.fd.uc.pt/publicacoes/coloquios/ ECLAN_2017.pdf >. Acesso em: 28 mar. 2019.

WEYEMBERGH, Anne, BRIÈRE, Chloé. Towards a European Public Prosecutor's Office (EPPO), Study for the Libe Committee. European Parliament, 2016. Disponível em <http://www.europarl.europa.eu/RegData/etudes/STUD/2016/571399/ IPOL_STU(201)571399_EN.pdf>. Acesso em: 28 mar. 2019.

VERVAELE, John, European Criminal Justice in the global context: challenges and perspectives. In: CAEIRO, Pedro (org.), Proceedings of the conference European criminal law in the global context: values, principles and policies, Coimbra: Instituto Jurídico/ Faculdade de Direito da Universidade de Coimbra, 2017. Disponível em <https://www.ij.fd.uc.pt/publicacoes/coloquios/ECLAN_2017.pdf>. Acesso em: 28 mar. 2019.

VERVAELE, John A. E. The material scope of competence of the European Public Prosecutor's office: a harmonised national patchwork?. Centro Studi di Diritto Penale Europeo, 2015. Disponível em <http://dirittopenaleeuropeo.it/wp-content/ uploads/2015/10/Vervaele-2014-15.pdf>. Acesso em: 28 mar. 2019. 


\section{Informações adicionais e declarações dos autores (integridade científica)}

Declaração de conflito de interesses (conflict of interest declaration): a autora confirma que não há conflitos de interesse na realização das pesquisas expostas e na redação deste artigo.

Declaração de autoria e especificação das contribuições (declaration of authorship): todas e somente as pessoas que atendem os requisitos de autoria deste artigo estão listadas como autores; todos os coautores se responsabilizam integralmente por este trabalho em sua totalidade.

Declaração de ineditismo e originalidade (declaration of originality): a autora assegura que o texto aqui publicado não foi divulgado anteriormente em outro meio e que futura republicação somente se realizará com a indicação expressa da referência desta publicação original; também atesta que não há plágio de terceiros ou autoplágio.

Dados do processo editorial (http://www.ibraspp.com.br/revista/index.php/RBDPP/about/editorialPolicies)

- Recebido em: 07/04/2019 Equipe editorial envolvida

- Controle preliminar e verificação de plágio:

- Editor-chefe: 1 (VGV) 09/04/2019

- Avaliação 1: 18/04/2019

- Avaliação 2: 22/04/2019

- Avaliação 3: 30/04/2019

- Editor-associado: 1 (PC)

- Editor-assistente: 1 (CRG)

- Revisores: 3

- Decisão editorial preliminar: 16/05/2019

- Retorno rodada de correções: 27/05/2019

- Decisão editorial final: 04/06/2019 


\section{COMO CITAR ESTE ARTIGO:}

SANTOS, Margarida. A implementação da Procuradoria Europeia - a emergência de um modelo de intervenção penal entre a cooperação e a integração penal? Revista Brasileira de Direito Processual Penal, Porto Alegre, vol. 5, n. 2, p. 999-1038, mai./ago. 2019. https://doi.org/10.22197/rbdpp.v5i2.240

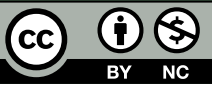

Esta obra está licenciada com uma Licença Creative Commons Atribuição-NãoComercial 4.0 Internacional. 